NON-LEGAL-TENDER PAPER MONEY:

THE STRUCTURE AND PERFORMANCE OF MARYLAND'S BILLS OF CREDIT, 1767-1775

\author{
Jim Celia \\ Farley Grubb
}

Working Paper 20524

http://www.nber.org/papers/w20524

\author{
NATIONAL BUREAU OF ECONOMIC RESEARCH \\ 1050 Massachusetts Avenue \\ Cambridge, MA 02138 \\ September 2014
}

The views expressed herein are those of the authors and do not necessarily reflect the views of the National Bureau of Economic Research.

NBER working papers are circulated for discussion and comment purposes. They have not been peerreviewed or been subject to the review by the NBER Board of Directors that accompanies official NBER publications.

(C) 2014 by Jim Celia and Farley Grubb. All rights reserved. Short sections of text, not to exceed two paragraphs, may be quoted without explicit permission provided that full credit, including $\odot$ notice, is given to the source. 
Non-Legal-Tender Paper Money: The Structure and Performance of Maryland's Bills of Credit, 1767-1775

Jim Celia and Farley Grubb

NBER Working Paper No. 20524

September 2014

JEL No. E31,E42,E51,N11,N21,N41

\begin{abstract}
$\underline{\text { ABSTRACT }}$
Maryland's non-legal-tender paper money emissions between 1765 and 1775 are reconstructed to determine the quantities outstanding and their redemption dates, providing a substantial correction to the literature. Over 80 percent of this paper money's current market value was expected real asset present value and under 20 percent was liquidity premium. It was primarily a real barter asset and not a fiat currency. The liquidity premium was positively related to the amount of paper money per capita in circulation. This paper money traded below face value only due to time-discounting and not depreciation. Past scholars have simply confused time-discounting with depreciation.
\end{abstract}

\author{
Jim Celia \\ Economics Department \\ University of Delaware \\ Newark, DE 19716 \\ jcelia@udel.edu \\ Farley Grubb \\ University of Delaware \\ Economics Department \\ Newark, DE 19716 \\ and NBER \\ grubbf@udel.edu
}




\title{
Non-Legal-Tender Paper Money: The Structure and Performance of Maryland's Bills of Credit, 1767-1775
}

\author{
Jim Celia and Farley Grubb ${ }^{1}$ \\ $(9 / 19 / 2014)$
}

Maryland's non-legal-tender paper money emissions between 1765 and 1775 are reconstructed to determine the quantities outstanding and their redemption dates, providing a substantial correction to the literature. Over 80 percent of this paper money's current market value was expected real asset present value and under 20 percent was liquidity premium. It was primarily a real barter asset and not a fiat currency. The liquidity premium was positively related to the amount of paper money per capita in circulation. This paper money traded below face value only due to time-discounting and not depreciation. Past scholars have simply confused time-discounting with depreciation.

In 1764, the British Parliament passed a currency act (4 Geo III c. 34) that prohibited the colonies south of New England from making new paper money emissions a legal tender, or from ex post facto extending the circulation time of pre-1764 legal tender paper money emissions (Ernst 1973, pp. 43-173; Greene and Jellison 1961; Labaree 1966, v. 9, pp. 131-53). Colonial legislatures, governors, and subjects thought making their paper money a legal tender was necessary to maintaining its circulation and upholding its value as a medium of exchange. Without a legal tender clause, paper money regimes were thought to be unsustainable and prone to rampant depreciation. Parliament's passage of the 1764 Currency Act was one of the major grievances the colonists had with the Crown leading up to the Revolution.

Before the passage of the 1764 Currency Act, all the colonies south of New England had emitted paper money in the form of bills of credit. These bills were structured as zero-coupon bonds with defined redemption dates and legal tender authority within the issuing jurisdiction (Grubb 2012a). The colonies were uncertain if this type of paper money could succeed as a medium of exchange and function as a substitute for real money (gold and silver coins) within

\footnotetext{
1 Jim Celia is an accounting and economics major at the University of Delaware, Newark, DE 19716. Farley Grubb is Professor of Economics and NBER Research Associate, Economics Department, University of Delaware, Newark, DE 19716. Send correspondence to Farley Grubb (grubbf@udel.edu). Editorial assistance from Tracy McQueen is gratefully acknowledged.
} 
their jurisdictions without being a legal tender. This uncertainty arose because large emissions of non-legal-tender paper money had never been tried in these colonies before.

The colonies lobbied against the passage of the 1764 Currency Act and, once passed, worked to repeal it. In the meantime, they hesitated to authorize new paper money emissions without legal tender status. The letters between the agents for several colonies to the British court and their respective colonial legislatures illustrate this concern and hesitation (Archives of Maryland v. 61, pp. c-ci; Behrens 1923, pp. 46-9; Ernst 1973, pp. 43-173; Greene and Jellison 1961, pp. 489-93, 503-6; Labaree 1967, v. 11, pp. 175-7; 1968, v. 12, pp. 47-61; 1969, v. 13, pp. 447-9, 465-7; 1970, v. 14, pp. 32-9, 76-88, 180-2, 185, 231-2, 285-8). When the Pennsylvania legislature finally decided in 1767 to make a trial emission of non-legal-tender paper money, Benjamin Franklin commented, "I am glad you made a Trial of paper Money without a legal Tender. The Quantity being small, perhaps may be kept up in full Credit notwithstanding...” (Labaree 1970, v. 14, p. 231, italics in the original).

Between 1764 and the Revolution, Delaware and New Jersey emitted no new paper money, though not for lack of trying. New Jersey had two paper money acts disallowed by the Crown in these years (Grubb 2013). After 1764, New York did not emit new paper money until 1771, Virginia not until 1769, and North Carolina not until 1768. The other colonies south of New England did not emit new paper money until 1767. Only Georgia showed no hesitation, issuing new paper money in 1765 and 1766 (Ernst 1973, Grubb 2012a, Newman 2008).

How did these non-legal-tender paper money emissions fare? Did the bills of credit that comprised these emissions function as “money," providing transacting services for executing local trades beyond that of the next best barter alternative? If yes, then to what degree did they serve this function? Did this paper money depreciate? Clearly, the 1764 Currency Act did not 
prevent the colonies from emitting paper money, as is often erroneously stated in the literature. But how these non-legal-tender paper money regimes were designed to work and how they performed in the decade before the Revolution has not been well studied.

The paper money emissions of colonial Maryland between 1765 and 1775 are used to answer the above questions. A model that decomposes the current market exchange value of this paper money into its expected real asset present value and its liquidity premium is presented and applied to the Maryland data. The model requires both an accurate measure of the amount of paper money outstanding each year, as well as a clearly identified redemption (maturity) date for each bill issued. Given that the current data on colonial money regimes do not provide this necessary level of accuracy and clarity, new data for Maryland is developed here first.

Colonial Maryland was chosen for this study for several reasons. First, Maryland had just redeemed and removed all its prior emissions of legal-tender paper money from circulation in 1764-65. These prior emissions and their 1764-65 removal date had been established in 1733, long before the passage of the 1764 Currency Act (Behrens 1923, pp. 12-45; Brock 1975, pp. 99106; Smith 1985, pp. 1,199-1,208). As such, the 1764 Currency Act likely caught Maryland offguard in terms of maintaining a flow of paper money circulating in their economy. The analysis of Maryland's post-1764 non-legal-tender paper money regime, therefore, is untainted by the continued circulation of pre-1764 paper money that was still considered a legal tender (Greene and Jellison 1961, p. 489; Grubb 2012a). By contrast, New Jersey kept a substantial amount of pre-1764 legal-tender paper money in circulation through 1775 (Grubb 2013, 2014). This historical accident allows the analysis of Maryland to isolate the new non-legal-tender paper money emissions from the old legal-tender paper money, and so uniquely measure the performance of the non-legal-tender paper money. 
Second, Maryland had established and maintained a track record of redeeming its paper money in specie (gold and silver coins or real money) at face value on time as legislatively promised. The relatively large emission in 1733 had been redeemed as promised: one-third in 1748 and two-thirds in 1764-65 (Behrens 1923, pp. 12-45; Brock 1975, pp. 99-106; Smith 1985, pp. 1,199-1,208). As such, subjects should attach no default risk to Maryland bills of credits. This condition is important because in the model and analysis that follows, risk discounts cannot be independently measured. Minimizing the effect of risk discounts enhances the confidence in the empirical results flowing from the model.

The study will proceed by first providing the political background to Maryland's monetary problems in 1764 . This background is followed by a political, legal, and execution analysis of each non-legal-tender paper money emission made by the Maryland legislature. This section establishes the amounts of paper money outstanding, their respective redemption dates, and the evolution in administrative mechanics of how paper money emissions were designed and executed. That section is followed by the development of a model to assess the performance of these paper money emissions, along with construction of the specialty data needed to make the model operational. The last two sections use this model to evaluate the market value of this paper money in terms of its expected real asset present value and its liquidity premium, as well as evaluate the determinants of that liquidity premium and the rate of depreciation. A conclusion finishes the paper.

\section{The "Want of Paper Currency": Maryland's Decision to Challenge the 1764 Currency Act}

The summer of 1764 was not an easy one for Governor Horatio Sharpe of Maryland. After making plans to redeem the last of the paper money the colony had emitted in 1733 from circulation as legislatively scheduled, Sharpe knew that the supply of Maryland paper money 
was about to vanish. In a letter to Cecilius Calvert (Lord Baltimore, the proprietor of the colony), Sharpe wrote in frustration, "I am inclined to think that the Trade of these Colonies must flag much from the Want of paper Currency” (Archives of Maryland, v. 14, p. 174). While good governance indicated that the colony should emit new paper money, there was an unexpected hurdle to clear, namely the recently passed 1764 Currency Act.

Maryland’s charter gave Lord Baltimore, not the Crown, sole responsibility for reviewing acts of Maryland's provincial legislature. To prevent the Crown from having reason to change this situation, the proprietor had given his governors standing orders to pass no paper money acts without his approval. He was not going to openly defy the 1764 Currency Act. Upon the advice of Governor Sharpe, however, Lord Baltimore found no fault with the non-legal-tender paper money acts proposed by the Maryland legislature. He allowed all such post-1764 acts to stand. Before 1770, the acts were not even provided to the Board of Trade, where the acts were seen as the best of their kind and an example for the rest of colonies to follow (Ernst 1973, p. 164).

After 1764, until the matter of emitting new paper money was resolved, Maryland subjects were left with just two options in terms of money: hard or real money, traditionally specie in the form of gold and silver coins; and bills of credit left over from the 1733 emission (Archives of Maryland, v. 14, p. 170). These bills, in the amount of £41,295 Maryland pounds, 11 shillings, 4 pence were expected to circulate until they were all redeemed "next Sept. to be paid off by sale of Bank Stock” (Archives of Maryland, v. 14, pp. 141, 170). This money was not enough to support the internal trade of the colony. In the words of Cecilius Calvert, the 1764 Currency Act's legal tender provision “must a[n]nihilate the valuable consequence of all such Paper Curren[c]y” (Archives of Maryland, v. 14, p. 141). With this knowledge, the leaders of Maryland began to work on a paper money act that would fall within the new legal restrictions 
(Behrens 1923, pp. 46-53; Ernst 1973, pp. 153-68).

In a letter to Calvert in December 1765, Governor Sharpe relayed initial plans for a new emission of paper currency that was purposely designed to circumvent the 1764 Currency Act. The Maryland legislature was comprised of an Upper and Lower House, similar to the House of Lords and House of Commons of the British Parliament. Approval of both Maryland's legislative Houses was required to pass paper money acts. In this period, the two Houses appear to have never disagreed over the necessity of emitting new paper money, but they stridently disagreed over the administrative mechanics of proposed paper money acts, so much so that final approval of these acts was often delayed for several years (Ernst 1973, pp. 153-68).

Both Houses agreed that Maryland should emit the same kind of bills of credit they had emitted pre-1764, but with the explicit restriction that these bills were not a legal tender (Archives of Maryland, v. 14, p. 252). The pre-1764 bills of credit were designed as zero-coupon bonds. The holders were able to redeem the bonds for a bill of exchange drawn on Maryland's account in London, composed of stock in the Bank of England, for a set amount of real money at a designated redemption or maturity date. As such, after 1764 the Maryland legislature would still be, in effect, emitting tradable bonds in the form of bills of credit. The legislature was simply hoping these bonds might function as a "money" even without official legal-tender designation.

Maryland had accumulated a sizable debt paying for its role in the Seven Years War. Maryland and Georgia were the only two North American colonies who received no Parliamentary reimbursements to help offset their contributions to that war effort (Greene 1980, p. 98). As such, part of the pressing need for a new paper money emission came from the legislature's intention to pay off these debts in paper money. At the end of 1765, Maryland's 
current war debt totaled nearly $\$ 135,000$ ( $\$=$ Spanish silver dollars). The legislature thought that if they required these new bills that would be used to pay off Maryland's creditors to stay in circulation for 10 years after their emission, the bills might function as a medium of exchange within the colony in those years. The emission would kill two birds with one stone, namely pay off the war debt and create an internal medium of exchange. At the end of 10 years, the bills would be redeemed by selling bank stock in the Bank of England held by Maryland's government in London, as had been done to redeem the 1733 paper money emission in 1748 and 1764-65 (Archives of Maryland, v. 14, p. 251).

With agreement over this initial plan, it was up to the Maryland legislature to build the administrative model for how such an emission would proceed. Before contacting Sharpe about their plan, the legislature decided that the proper amount of money for emission was $\$ 135,000$, namely the exact amount of Maryland's war debt. These new bills, unlike Maryland's previous bills, would be denominated in Spanish silver dollars, to signify that they were designed to pay off the war debt, and not necessarily intended to be a new form of money in violation of the 1764 Currency Act. These new bills of credit were to be exchanged at redemption at the rate of four shillings and six pence sterling per Spanish silver dollar $\left(\$ 4.4444=1 £_{\mathrm{s}}\right)$-meaning that the emission would have to be backed by at least $30,375 £_{\mathrm{s}}\left(£_{\mathrm{s}}=\right.$ pounds sterling) worth of cash and bank stock held in London when the bills were to be redeemed 10 years later (Archives of Maryland, v. 59, p. 183).

While the initial plan looked promising, legislators were uncertain over how much value the bank stock in the sinking fund would bring in over 10 years through accumulated dividends. The market value of the bank stock at the point of redemption, as well as the accumulated interest the stock generated, was crucial for the implementation of the plan, as the stock served as 
a sinking fund backing the redemption of the bills. ${ }^{2}$ They estimated what the sinking fund would be at redemption, assuming that the sinking fund of Bank of England stocks paid an "Annual Dividend of 5 p'cent...” (Archives of Maryland, v. 59, p. 184).

At the end of 1765 , Maryland had $36,000 £_{s}(\$ 160,000)$ remaining in the sinking fund, and in various accounts, after redeeming all the remaining pre-1764 bills. Even with no tax revenue added to the fund, as was done yearly from 1734 through 1764, the yearly dividend of 5 percent added back into the fund would make the fund grow to $50,400 £_{\mathrm{s}}(\$ 224,000)$ at simple, interest, and to $61,572 £_{\mathrm{s}}(\$ 274,000)$ at compound interest, by 1777 . Thus, by the redemption (maturity) date of the bills, 10 years from 1767, there would be more money in the sinking fund than was needed to execute redemption at face value of the amount being considered for emission in 1765 (Archives of Maryland, v. 14, pp. 254-5, 390; v. 59, 183-4; v. 61, p. ci).

The initial plan would leave $31,197 £_{\mathrm{s}}(\$ 138,652)$ of bank stock remaining in Maryland's possession after the $\$ 135,000$ bills of credit were redeemed. As such, the legislature could increase the size of its paper money emission beyond what was needed to pay off Maryland's war debt. Not surprisingly, over the course of the late 1765 session, the amount of money proposed to be emitted expanded to $\$ 140,000$ (Archives of Maryland, v. 59, pp. 191-3).

The work to emit these first non-legal-tender bills was far from over. There were two matters that delayed passage. The salary for the Clerk of his Lordship’s Council of State caused the first part of the delay. The legislative Houses debated how to set extra money aside until it was decided whether or not this clerk would be paid, i.e. whether his pay was the responsibility

\footnotetext{
2 The sinking fund was created by the 1733 paper money act. It was filled by imposing a 15d sterling tax on each hogshead of tobacco exported from Maryland and then investing that revenue in stock in the Bank of England. The tax monies going into the fund were to span the 1733 paper money emission, namely from 1734 to 1764 . Over this period the fund accumulated more value than what was needed to redeem the 1733 emission in 1748 and $1764-65$ as legislated in the 1733 Act. On 24 December 1765, Governor Sharpe stated that 25,000£ remained in the account in London after redemption of the last the 1733 bills, and that an 11,000 $£_{\mathrm{s}}$ surplus in Maryland was being sent to add to that account, making for a total of 36,000£ available in the sinking fund in 1766 (Archives of Maryland, v. 14, pp. 254-5; Behrens 1923, pp. 12-45; Brock 1975, pp. 99-106; Price 1977; Smith 1985, pp. 1,199-1,208).
} 
of Maryland or the proprietor, Lord Baltimore. The Lower House wanted to take care of the matter on their own, holding the new paper money for this clerk's salary and paying him if the necessity arose. Not surprisingly, the Upper House was not fond of the idea, and suggested that equal parts of this clerk's salary be paid to both the Upper and Lower House, and if the money was not paid to this clerk, the two Houses would obtain an equal share of the surplus (Archives of Maryland, v. 61, pp. 108, 215).

The second point that delayed passage was the potential for a surplus as a result of selling the bank stock. At present, the new paper money act did not provide any guidance for who would be in charge of spending the potential surplus arising from the sale of bank stock at redemption. The Upper House insisted that the surplus, if one were to arise, was to be apportioned in an equitable way, while the Lower House thought other uses might be more important. These disagreements between the two Houses were thrown back and forth for two years, while both Houses remained "sensibly affected with the distressed Circumstances of the Province, and the extream Necessity of many of the Creditors of the Public, occasioned, in great Measure, by the want of a Circulating Medium of Commerce, and by the Non-payment of the Public Debt” (Archives of Maryland, v. 61, pp. 105, 129).

\section{The Political Economy and Quantitative Reconstruction of the Paper Money Emissions}

\section{a. The First Non-Legal-Tender Emission (1767): Political Economy Analysis}

On 6 December 1766, the two-year struggle to issue new paper money in Maryland was concluded with the passage of an act titled, “An Act for the payment of the Publick Claims for emitting Bills of Credit and for Other Purposes therein mentioned” (Archives of Maryland, v. 61, p. 132; Behrens 1923, pp. 47-53). This act is referred to here as the 1767 Act. It constituted a compromise between the two Houses in the interest of emitting the much needed paper money. 
The 1767 Act emitted $\$ 173,733$, a sign that the legislators not only hoped to pay the creditors with this emission, but also intended to issue plenty of extra currency.

The bills, instead of being denominated in pound-style units of account as were earlier Maryland paper monies and most other colonial paper monies, were denominated in Spanish silver dollar units of account. The largest was an $\$ 8$ bill, and the smallest was a $\$ 1 / 9$ bill. These 1767 bills of credit would be redeemed at face value for bills of exchange after 10 years. The bills of exchange were "payable in London at the rate of Four shillings and six pence [sterling] per [Spanish silver] Dollar” (Archives of Maryland, v. 61, pp. 264-6; Newman 2008). By 1777, after redemption, the sinking fund was still expected to have $22,560 £_{\mathrm{s}}(\$ 100,267)$ at compound interest in the account, absent any other withdrawals. ${ }^{3}$

Two commissioners and one clerk were appointed to carry out the emission of the bills of credit, with the commissioners explicitly authorized to pay back Maryland's creditors. In the 1767 Act, salaries of $\$ 250$ per commissioner and $\$ 200$ for the clerk in bills of credit were to be set aside as part of the emission. The commissioners earned a higher salary because they were also responsible for attending the printing presses, to ensure it was done according to standards. The printer was paid $\$ 800$ in bills of credit. The act prescribed "Death as a Felon or Felons without Benefit of Clergy" for those who counterfeited the new Maryland bills (Archives of Maryland, v. 61, pp. 266-9, 272). This was the typical penalty imposed by most colonies for counterfeiting (Newman 2008, Scott 1957).

The 1767 Act paid considerable attention to the elements on which the two Houses initially disagreed, particularly on the matter of the handling the salary of the Clerk of his Lordship’s Council of State. It was decided that $\$ 1,703.10$ for this clerk’s overdue pay, and

\footnotetext{
${ }^{3}$ Ernst (1973, p. 165) erroneously states that these bills would be redeemed in 1771, rather than in 1777.
} 
$\$ 85.20$ for general purposes, in bills of credit, would be paid to the Treasurer's Commission, an independent third party. This clerk's wages would be "put out at interest" until it was decided whether this clerk would be paid by Maryland. The dispute over who was responsible for this clerk’s salary had been sent to the Crown for arbitration. To resolve the other point of discord, namely the disposition of any potential surplus from the sale of bank stock at redemption, the 1767 Act provided that the interest and profit from the bank stock, as well as all "penalties and Forfeitures” were to be “applyed and Disposed of as the General Assembly shall direct and appoint” (Archives of Maryland, v. 61, pp. c, 271, 275).

Three important aspects of the paper money act received little to no debate, namely how long the bills of credit would stay in circulation before being redeemed for bills of exchange, how the redemption process would function, and whether yearly interest would be paid on the bills of credit. The bills were to stay in circulation for 10 years from their emission date, with a redemption window that spanned a year and a half thereafter. From 25 June 1777 to 25 December 1778, holders of bills of credit could return the bills to the commissioners and receive bills of exchange. These bills of exchange were payable in London at the rate of four shillings and six pence pounds sterling per Spanish silver dollar redeemed. They entitled the holder to receive the stated amount from the trustees of Maryland's sinking fund in London via the trustee’s selling Maryland's holdings of Bank of England bank stock (Archives of Maryland, v. 61, pp. 273-4).

As the redemption window opened, the trustees would begin selling the Bank of England bank stock in their possession for "the best price that can be had for the same thereby to raise Monies for the payment of the said Bills of Exchange” (Archives of Maryland, v. 61, p. 274). With this money, the holders of the bills of exchange would be paid back. The bills of credit so 
redeemed for bills of exchange would be counted and burned by the commissioners. In the interim between emission and redemption, Maryland's bills of credit paid no interest. As such, they functioned as zero-coupon bonds, with maturity dates for redemption at face value, but with no coupon value in the interim. This zero-coupon feature would be true of all three non-legaltender emissions between 1767 and $1774 .^{4}$

On 9 June 1767, Governor Sharpe wrote (Archives of Maryland v. 14, p. 390), Would our Assembly lay a small Duty on Tobacco exported \& on all Rum to be hereafter imported for the purpose of making an Annual Addition to our Bank Stock It would I apprehend be greatly for the Interest \& prosperity of the Province \& vastly encourage \& increase our Trade to add £30,000 to our late Emission but I do not know that any such Intention is entertained, nor should I choose to go a Step farther without having previously obtained His Ldp’s Assent.

As far as can be determined, the legislature never added any tax revenue to the sinking fund after 1765. They counted only on the dividends earned by the fund for its growth over time.

Finally, the 1767 Act closed with an important line that ensured the bills would be able to skirt the rules of the 1764 Currency Act, namely "Provided always and it is the True intent and meaning of this Act that nothing herein contained shall Extend or be Construed or taken to make any Tender... lawfull Except such Contracts as shall or may be made expressly” (Archives of Maryland, v. 61, p. 275). This phrase delineates the necessary rule that unless there was a stated contract for delivery of bills of credit, they were not intended to be used as legal tender for payment or as a legal remedy in cases involving restitution for the non-payment of debts.

By intentionally defining the bills as not being a legal tender, the Maryland government had confined the circulation of these bills to a secondary market where they were traded purely as bonds, but hopefully a secondary market that was liquid enough that the bonds would trade

\footnotetext{
${ }^{4}$ Greene and Jellison (1961, pp. 493, 505) erroneously claim that Maryland's post-1764 bills of credit paid annual interest. The sinking fund of bank stock used to redeem the bills of credit accumulated interest (dividends), but not the bills of credit themselves. These authors simply confused the two.
} 
with enough frequency that they might be considered as money-like instruments. The Maryland government had, through careful wording, developed a substitute non-legal-tender paper money system that was virtually identical in structure to their pre-1764 legal-tender paper money system. They hoped this new paper money would put an end to their woes and alleviate the “distressed Circumstances of the Province” (Archives of Maryland, v. 61, p. 105).

\section{b. The First Non-Legal-Tender Emission (1767): Quantitative Analysis}

How closely did the actual emission schedule match the Act's intent? Table 1 answers this question by showing the planned emission schedule and the actual execution of emissions. The planned emission in the 1767 Act was rather straight forward, namely $\$ 173,733$ was to be emitted in 1767, with that amount staying outstanding through 1775 . The legislature's Journals of Accounts, however, tell a different story (Behrens 1923, p. 52).

The payments due to public creditors was stated to be about $\$ 135,000$ in December of 1765 , yet the payment made in bills by the end of 1767 was $\$ 152,979$. The difference is consistent with the government making an added payment of accrued interest, at 6 percent, on its unpaid debts over this two year period. In 1767, given that creditors more-or-less had to agree to take these bills at their face value in specie as payment for the specie debts owed them, and given that these bills were not redeemable in specie at their face value for 11 years, indicates that creditors may have taken a considerable "haircut" (loss of value) on their loans to the government. No alternative payment scheme was on the horizon, meaning that if creditors did not take this deal they might never receive anything (Archives of Maryland, v. 14, p. 251; v. 61, pp. 264-9).

At a 6 percent discount rate, if creditors treated the bills as bonds and held them to redemption to recover the specie owed them, they lost about 50 percent of their initial value, in 
Table 1. Planned and Actual Emissions under the 1767 Paper Money Act, 1767-1775

\begin{tabular}{|c|c|c|c|c|c|c|c|}
\hline \multirow[b]{2}{*}{ Year } & \multicolumn{2}{|c|}{$\begin{array}{l}\text { Emissions to Public } \\
\text { Creditor }\end{array}$} & Una & pplied & \multirow{2}{*}{$\begin{array}{l}\text { Salaries and } \\
\text { Clerk's Pay Put } \\
\text { Out on Interest } \\
\text { (Planned = Actual) }\end{array}$} & \multirow{2}{*}{$\begin{array}{l}1767 \text { Bills } \\
\text { Outstanding } \\
\text { Planned }\end{array}$} & \multirow{2}{*}{$\begin{array}{l}1767 \text { Bills } \\
\text { Outstanding } \\
\text { Actual }\end{array}$} \\
\hline & Planned & Actual & Planned & Actual & & & \\
\hline 1767 & $\$ 170,444.70$ & $\$ 152,978.70$ & $\$ 0$ & $\$ 17,466.00$ & $\$ 3,288.30$ & $\$ 173,733.00$ & $\$ 156,267.00$ \\
\hline 1768 & 0 & 0 & 0 & --- & 0 & $173,733.00$ & $156,267.00$ \\
\hline 1769 & 0 & 0 & 0 & $18,930.39$ & 0 & $173,733.00$ & $154,802.61$ \\
\hline 1770 & 0 & $3,412.01$ & 0 & $15,518.38$ & 0 & $173,733.00$ & $158,214.62$ \\
\hline 1771 & 0 & 0 & 0 & -- & 0 & $173,733.00$ & $158,214.62$ \\
\hline 1772 & 0 & 0 & 0 & --- & 0 & $173,733.00$ & $158,214.62$ \\
\hline 1773 & 0 & $1,879.40$ & 0 & $13,638.98$ & 0 & $173,733.00$ & $160,094.02$ \\
\hline 1774 & 0 & 0 & 0 & --- & 0 & $173,733.00$ & $160,094.02$ \\
\hline 1775 & 0 & 0 & 0 & --- & 0 & $173,733.00$ & $160,094.02$ \\
\hline
\end{tabular}

Sources: See the text.

Notes: Dashes indicate missing data. The clerk’s pay that was put out on interest was $\$ 1,788.30$, and was for the Clerk of his Lordship’s Council of State. Salaries, totaling $\$ 1,500$, were to pay the printer, clerk, and commissioner who processed and administered the 1767 paper money act.

present value terms. If the goal of the 1764 Currency Act was to prevent this type of government debt reduction via paying current specie debts with bills of credit, it failed here. The scheme went unrecognized for what it was. No protests to this scheme were recorded. This lack of recognition appears to come from both creditors and the government hoping that the bills would acquire extra value as a preferred medium of exchange, beyond their bond value, and so mitigate or even eliminate any possible haircut imposed on public creditors. This expectation or belief may explain the apparent acquiescence in this scheme by all parties. ${ }^{5}$

The amount of bills printed and designated to cover public debts, $\$ 170,445$, was greater than what was needed to do so. In setting the bills to be emitted at an amount in excess of that due immediately to creditors, the Maryland government ran the risk of not emitting all of the bills authorized if other expenses were not incurred. While records for the 1767 legislative

\footnotetext{
${ }^{5}$ Some war debts appear to have been initially contracted in tobacco and old paper money units of account, rather than directly in specie (Archives of Maryland, v. 61, pp. 264-5). Whether original debt pricing compensated for an expected repayment haircut, or whether contracts in non-specie units of account gave creditors little standing for redress when repaid in bills of credit, is unclear. Either possibility would mitigate the haircut implied here.
} 
sessions were not officially kept, it appears that as of 5 March 1767 the amount of bills left unissued was \$17,466 (Archives of Maryland, v. 61, p. ci). These additional bills were to be held in the iron chest in the loan office, and each subsequent Journal of Accounts issued by the loan office shows how much of the original emission was left unapplied in the chest.

By 1769 , the amount left unapplied had increased to $\$ 18,930.39$. This increase was likely caused by the repayment of debts owed Maryland in the form of the bills of credit, lowering the amount of bills left outstanding. The amount of the 1767 emission left unapplied fell over time, first to $\$ 15,518.38$ in 1770 , and then to $\$ 13,638.98$ in 1773 (Archives of Maryland, v. 62, pp. 32, 107; v. 64, p. 50). For the amount of bills in the iron chest to decrease, these bills must have been emitted via payments for government expenses and so were outstanding at the time the Journal of Accounts was prepared, see Table 1.

With regard to the two specifically denoted outlays in the 1767 Act—-the overdue salary for the Clerk of his Lordship's Council of State and the salaries of the printer, clerk, and commissioners managing the paper money emission—no mention is made in future Journals of Accounts of these payments being made. As such, it is reasonable to assume that the legal recommendations for payments were followed in the first year.

With these calculations in mind, Table 1 shows how the 1767 emission actually proceeded, and provides an important corrective to past estimates. Data for Maryland's paper money outstanding presented in the Historical Statistics of the U.S. reports that the full $\$ 173,700$ was emitted in 1767 (Carter 2006, v. 5, p. 693; Ernst 1973, p. 369; Price 1977, p. 8). While this was the original intent of the law, the historical record shows that the reality of the emission deviated significantly from the plan. For the government of Maryland, this would not be the last time they would deviate from the original emission plan legislated. 


\section{c. The Second Non-Legal-Tender Emission (1770): Political Economy Analysis}

The legislative process for the second emission of Maryland's non-legal-tender paper

money was more streamlined, rapid, and less contentious than for the first emission. On 28 November 1769, the Lower House "resolved itself into a Committee of the whole House to take into Consideration the Expediency and the Ways and Means of issuing Bills of Credit, for the Improvement of the Province, and the Advancement of the Trade thereof.” Within a day, the Lower House resolved not only that a second emission was wise, but also determined that they should increase the emission size to $\$ 300,000$, almost twice the size of the first emission (Archives of Maryland, v. 62, pp. 53-4; Behrens 1923, pp. 53-4; Ernst 1973, pp. 167-8).

Whether it was the first emission's effectiveness in promoting internal trade, or the fact that disagreements over the administrative details of paper money acts had been resolved in the writing of the 1767 Act, passage of this second act occurred with minimal debate. In little over two weeks, the Lower House developed the act for administering the new emission. It passed both the Lower and Upper Houses by 16 December 1769. It was titled "An Act for emitting Bills of Credit and other Purposes therein mentioned” (Archives of Maryland, v. 62, p. 151). It is referred to here as the 1770 Act. Despite the lack of debate over its administrative details, the 1770 Act included major technical changes compared with its 1767 predecessor.

The 1770 Act differed from the 1767 Act in that more bills were printed under the 1770 Act than were to be emitted. Only $\$ 300,000$ were to be signed and numbered by the commissioners, yet the 1770 Act instructed that $\$ 318,000$ worth of bills were to be printed. Printing $\$ 18,000$ spare bills is explained by the Houses' concern over how to deal with torn and defaced bills. These spare bills were intentionally set aside to exchange for those that had been damaged and could no longer continue in circulation. This action ensured that the currency 
outstanding would remain at the levels intended (Archives of Maryland, v. 62, pp. 133, 137, 142; Behrens 1923, p. 53). As long as the commissioners followed through in their duty to burn the damaged bills, the amount intended to be outstanding from this second emission, i.e. $\$ 300,000$, would be unchanged by this additional reserve of $\$ 18,000$ printed bills.

The 1770 Act also differed in the mode of emission. In the 1767 Act, bills were emitted primarily through the payment of Maryland's war debts. While Maryland accumulated some debts between 1767 and 1770, they were not enough to serve as a basis for emission. With no central bank structure, Maryland would have to create its own special purpose "bank" to begin circulating the 1770 bills. The bank structure described in the 1770 Act is that of a land bank. To take out a loan of bills, a person had to own property in Maryland. For the first six months of the emission (in 1770), each property holder could only borrow between $\$ 100$ and $\$ 1,000$. Each borrower was required to give a bond, on which they would pay 4 percent interest each year. At the beginning of the final year of the emission (1781), the principal payments on the bonds were to be "called in" by the Maryland government, and no more 1770 bills were to be loaned out (Archives of Maryland, v. 62, pp. 138-9, 143).

After the first six months of the emission, there was no upper limit on the sum that could be lent to one individual property holder, but there were other restrictions. Any loans exceeding $\$ 3,000$ required that the borrower enter into a separate bond with one of the commissioners for each increment of $\$ 3,000$ borrowed. In addition, these borrowers had to have "one or more Sureties who at the Time thereof shall not be bound as Sureties in the said Office for any Sums to the amount in the whole of more than Four Thousand Dollars" (Archives of Maryland, v. 62, p. 139). By insisting that the borrowers had other financial backers who also had to own property in the colony, the Maryland government reduced the default risk on the loans to near zero. 
The borrowers, and their sureties, on all loans had to continue to own property in Maryland throughout the life of the bond, as the bonds themselves constituted a lien on the property. This property needed to be worth double the value of the amount which was to be lent to the borrower. Leaving the colony or failing to make an interest payment meant the borrower and their sureties would be subject to seizure of goods and lands to pay their debt to the Maryland government (Archives of Maryland, v. 62, p. 140).

The legislature had set up a system in which their risk of losing money on these paper money loans was nearly nonexistent, which allowed them to offer the below-market interest rate of 4 percent on the loans. This below-market rate incentivized subjects to borrow all the bills available. The loan portion of the paper money act appears to have always been fully subscribed.

The third difference between the 1767 and 1770 Acts involved how any surplus money made from the 1770 Act was handled. In the 1767 Act, the debate over how to handle any surpluses in the sinking fund at redemption was settled with the resolution that any surplus money was to be applied by the general assembly as a whole. With the land bank structure as set up in the 1770 Act, surpluses were not only possible, but were now a sure outcome given that yearly interest had to be paid by paper money borrowers. As such, when developing the 1770 Act, the legislature felt it prudent to have an explicit plan for how to handle the interest income. The 1770 Act required the annual interest paid on the loans, as well as any principal payments made, to be loaned out again, if there were willing borrowers (Archives of Maryland, v. 62, pp. 142, 147). This action would maintain the amount of paper money outstanding at its initial level. This procedure of relending annual interest payments, and relending any principal payments, not only maintained all the 1770 bills in circulation, but expanded the loan principal beyond the initial $\$ 300,000$ lent. This expansion meant that at the end of the loan period, when 
the principal of all loans under the 1770 Act were called in, there would be more loan principal and interest due at redemption than there were 1770 bills currently outstanding. Not only would the redemption process redeem (and so cancel) all the bills of the 1770 emission, but it would generate excess specie income. Borrowers who could not pay off their principal and interest at the redemption date in bills had to pay in specie at the bill's face value equivalent. No money from the sinking fund would be required to redeem the 1770 bills.

Finally, a major change in the 1770 Act compared with the 1767 Act was the introduction of variable contingency expenses. In the 1767 Act, all expenses to be paid in bills of credit, such as clerk and commissioner salaries, were pre-designated to be paid by the treasurer. While the clerk and commissioners who managed the paper money emission were to be paid again in bills of credit in the 1770 Act, new potential expenses were included in the "Purposes therein mentioned” for the 1770 emission (Archives of Maryland, v. 62, pp. 136-7). These contingency expenses were primarily for repairing the Stadt [State] House in Annapolis. They were only to be paid in newly printed bills if taxes to pay the expenses were deficient.

The Stadt House had decayed over the years and required maintenance work. After much debate, the Maryland government agreed to cover the repairs through tax revenue and bills of credit. If tax revenues fell short, the Maryland government would use up to a maximum of $7,500 £_{s}$ or $\$ 33,333.33$ of newly printed bills from the 1770 Act's contingency fund to cover this expense (Archives of Maryland, v. 62, pp. 149-50). These bills would be diverted from the pool of loanable bills available in the land-bank loan office, thus reducing the amount of bills out on loan. However, any paper money extracted through taxes, as the result of this spending, would remain in circulation and so maintain the initial levels of paper money outstanding.

Aside from these additional features, the legal framework and administrative mechanics 
of the 1770 Act remained the same as in the 1767 Act. The bills were printed according to the same standards; commissioners and a clerk were hired to oversee the emission and redemption of the bills, and the bills were again designated to not be a legal tender. However, as a result of switching to the land bank method of emission, the redemption process became more complex.

In the last year (1781) of the 12 years spanned by the 1770 emission (1770-1782), no more bills of this emission would be lent out. In the first six months of this final year, from 10 April 1781 to 10 October 1781, all of the loans the colony made in 1770 bills were to be called in, and debtors were required to make their principal payments. After this six month window, the colonists had six months, until 10 April 1782, to redeem any 1770 bills of credit still in their possession for bills of exchange which functioned just as they had under the 1767 Act, namely for claims on the specie monies in the sinking fund (Archives of Maryland, v. 62, p. 143).

This last feature of the 1770 Act is important to the administration and mechanics of the paper money system. At redemption in 1781, when all the loans made in 1770 bills would be called in and thus cancelled, it was possible that there would not be enough 1770 bills to pay all the loan principal and interest owed from the borrowings of these bills. The relending of annual interest payments built into the structure of the 1770 Act created this outcome. As such, some borrowers would have to pay off their loans in specie at the equivalence printed on the face of the bills (Newman 2008, pp. 171-3). As such, the redemption process could potentially cancel all the 1770 bills outstanding, and leave none in anyone's possession to be redeemed by swapping them for bills of exchange, that would draw specie money from the sinking fund.

However, at redemption it is unlikely that the distribution of 1770 bills in the economy would be perfectly aligned with the distribution of borrowers who had to pay off their loans and final interest payments in these bills. If redemption was stipulated to be only in these bills, not 
only was that not possible as the total loan principal exceed the amount of bills outstanding at the date of redemption, but that stipulation would require subjects who owed loan principal payments to scramble at the redemption date to acquire bills from subjects who did not owe loan principal payments. This imbalance of bills across subjects at the date of redemption between those possessing bills and those owing bills created the potential for hold-ups and extortion of one subject against another. By allowing subjects to pay off their paper money loans and final interest payments in specie equivalents, the Maryland legislature not only anchored the value of the paper money to this specie equivalence at the date of redemption, but removed the hold-up problem caused by the likely imbalance of bills across subjects at the date of redemption. While not making the bills a legal tender, the legislature had, in effect, created the same value anchor, namely a fixed exchange rate between bills and specie at the date of redemption that had served as the value anchor of bills in the pre-1764 era of legal-tender paper money.

Finally, by allowing subjects to pay off their loans in specie equivalents, the actual redemption process might not cancel all the 1770 bills outstanding at the date of redemption. If subjects who were borrowers did not possess bills and subjects who were not borrowers possessed bills, then the redemption process might be largely in specie leaving a lot of 1770 bills still outstanding. In this case, the legislature had solved the problem by basically making bills and specie fungible at the date of redemption. If specie was used to pay off the loans of 1770 bills, then the specie received could be channeled into the sinking fund. It would be enough to cover the redemption of outstanding 1770 bills in the hands of non-borrowers when they were required to trade them for bills of exchange that drew specie money from the sinking fund.

The land-bank relending structure of the 1770 Act meant that the 1770 bills would, in effect, redeem themselves with no additional net claim on the sinking fund. Therefore, not only 
did the legislature not have to add any new tax revenues to the sinking fund, but they could withdraw funds from the sinking fund that were judged to be in excess of what was needed to redeem the 1767 bills. The legislature estimated that only $24,000 £_{s}$ would be needed in the sinking fund, starting in 1766, to fully redeem the bills of the 1767 emission at their 1777-1778 redemption date. With dividends accumulating at 5 percent, at compound interest, $24,000 £_{\mathrm{s}}$ $(\$ 106,666)$ in 1766 would grow to $41,048 £_{s}(\$ 182,434)$ by 1777 , more than enough to redeem all $\$ 173,733$ paper bills authorized by the 1767 Act. Given this, and the fact that in 1766 the sinking fund had $36,000 £_{\mathrm{s}}$ currently in it, the legislature at the end of 1769 ordered the immediate sale of $10,000 £_{\mathrm{s}}$ of bank stock for the use of the province (Archives of Maryland, v. 14, pp. 251, 390; v. 59, 183-4; v. 61, p. ci; v. 62, p. 145; Behrens 1923, p. 53). With the 1770 Act passed, the duty lay in the hands of the commissioners and the clerk to follow the new procedures for emission. d. The Second Non-Legal-Tender Emission (1770): Quantitative Analysis

For the commissioners, the second non-legal-tender emission was more intricate than the first and, thus, more demanding to execute. The initial emission of $\$ 300,000$ was followed by a recirculation of any bills used to pay interest and principal on the loans or to pay any debts previously owed to the colony. To make matters more difficult, nothing in the 1770 Act said that these debts had to be paid in the same 1770 bills of credit-meaning that the debts and fees could be paid in 1767 bills of credit or in specie.

For the purposes of analyzing the 1770 Act, it is assumed that the interest was paid in 1770 bills, which were then immediately loaned out again. This process led to an accumulation of interest and an expansion in the total loan principal outstanding, but no change in the amount of 1770 bills outstanding. The salaries that the clerk and commissioners were supposed to receive were also not specify to necessarily be paid in 1770 bills. Based on the way the 1770 Act 
was written, it is assumed that the clerk and commissioners were paid in leftover unapplied 1767 bills, see Table 1. The Stadt House expenses are assumed to be completely covered by tax revenue, given no evidence to the contrary. Table 2 shows the ideal and actual circulation and recirculation process for the first five years of the 1770 emission.

This simplified execution process does not appear to deviate from the end results of what actually occurred. As of 30 October 1770, the Journal of Accounts noted that, "the Commissioners... pursuant to the directions of the Act of Assembly, Emitted 300,000 Dollars in Bills of Credit.” The debts owed by a few colonists that were called in were paid in pounds sterling, making them irrelevant to the recirculation of bills. Finally, as expected, the $\$ 18,000$ worth of extra money printed was officially set aside "to be Signed, and Delivered in Exchange for Torn and Defaced Bills” (Archives of Maryland, v. 62, pp. 196-7).

The 1773 Journal of Accounts makes no mention of using bills of credit to pay for the repairs on the Stadt House. Tax revenues, therefore, must have been sufficient to cover this expense. As such, while at first it appeared that the commissioners faced a more difficult task dealing with the demands of the new 1770 emission, the only functionally new segment they had to deal with, besides re-loaning any interest and principal payments received in 1770 bills, was the exchange of torn and defaced bills for those spare bills held in the iron chest. Over the first three years of the 1770 emission, the commissioners exchanged $\$ 10,094.28$ bills for these spare bills, burning the defaced bills so exchanged (Archives of Maryland, v. 64, pp. 50-3). Given that the actions taken in 1774 were the same as in 1773 , the actual emission procedure for the 1770 emission appears to be as initially planned and shown in Table 2.

Just as with the 1767 emission, the 1770 emission schedule for the amount of bills outstanding shown in Table 2 does not match the current historical record as provided in the 
Table 2. Planned and Actual Emissions under the 1770 Paper Money Act, 1770-1775

\begin{tabular}{lccr}
\hline & $\begin{array}{l}\text { Total Loans } \\
\text { Outstanding (Initial } \\
\text { Plus Re-issued) }\end{array}$ & $\begin{array}{l}\text { Payments of Interest on Loans } \\
\text { (Re-loaned by Government and so } \\
\text { Put Back in Circulation) }\end{array}$ & $\begin{array}{l}\text { 1770 Bills } \\
\text { Outstanding }\end{array}$ \\
\hline 1770 & $\$ 300,000.00$ & $\$ 12,000.00$ & $\$ 300,000.00$ \\
1771 & $312,000.00$ & $12,480.00$ & $300,000.00$ \\
1772 & $312,480.00$ & $12,979.20$ & $300,000.00$ \\
1773 & $312,979.20$ & $13,498.37$ & $300,000.00$ \\
1774 & $313,498.37$ & $14,038.30$ & $300,000.00$ \\
1775 & $314,038.30$ & $14,599.83$ & $300,000.00$ \\
\hline
\end{tabular}

Sources: See the text.

Historical Statistics of the U.S., which reports the full amount printed, \$318,000, as the actual amount emitted. This estimate overlooked that $\$ 18,000$ of the bills printed were exclusively to be used as a reserve for exchanging bills that were too torn or defaced to continue in circulation. They were not a net addition to the amount outstanding (Carter 2006, v. 5, p. 693; Price 1977, p. 8). Behrens (1923, p. 53); Ernst (1973, p. 369); and Greene and Jellison (1961, p. 494) report the correct initial authorized total $(\$ 300,000)$, but do not report the amounts outstanding over time. e. The Third Non-Legal-Tender Emission (1774): Political Economy Analysis

Having passed two acts to emit bills of credit, the Maryland legislature appeared satisfied with the performance of their dollar-denominated, non-legal-tender paper currency. While the bills were not a legal tender, they appear to have filled the void left by the redemption of the 1733 legal-tender paper money. Governor Sharpe concluded as early as 1767 that,

If the Ministry have no Objections to the [paper money] Plan Maryland has adopted We shall be very indifferent whether the Parliament takes off or continues the Restraint laid on the Colonies by the Law [the 1764 Currency Act]...indeed I think it is for our interest it should continue in force since our Mercantile People have now money for the purposes of Trade while those in the neighbouring Colonies are stinted as it were for Want of a Circulating Medium... (Archives of Maryland, v. 14, pp. 390-1).

By November 1771, the legislature was eager to initiate a third emission, having already 
drafted a new act. While this act passed the Upper House, with a few amendments, the law's development came to a halt over the matter of a certain cash outlay. The third emission, like the 1770 emission, included contingency expenses that could be paid out of the interest income arising from the loans of the paper money. One of these expenses was $\$ 42,666.67$ for "the purpose of Establishing a Seminary of Learning in this Province.” This expense was equal to the first four years of interest income from loaning out the paper money proposed in the act. The Lower House refused to strike the portions of the act related to the seminary's establishment and the use of the interest income for its support. The Upper House, in turn, refused to approve the act as it meant they would have no say in the application of this interest income (Archives of Maryland, v. 63, pp. 28, 35, 169). As the 1771 legislative session drew to a close, the two Houses only agreed that more bills should be emitted. This was not enough to pass the act.

The matter of emitting more bills was brought up again in 1773. On the second attempt, the process of passing the new act, titled "An Act for Emitting Bills of Credit and applying part thereof,” proved more expedient than the first attempt. On 16 December 1773, the act was presented to the Lower House and passed, and by the 21st, the act had passed both Houses (Archives of Maryland, v. 64, pp. 69, 257). With persistence, the Lower House claimed their victory and their right to apply the first four years of the interest income from loaning out this new paper money toward funding the seminary of learning for which they fought in 1771 . This third emission of non-legal-tender paper money is referred to here as the 1774 Act.

In many respects, the 1774 Act was similar to its predecessor. As always, the bills of credit were not made a legal tender, and the administration of the emission was to be managed by a clerk and two commissioners. The bills were planned to be emitted through the same land bank method as the 1770 Act, at the same 4 percent rate of interest. The requirement and procedures 
for loaning out the paper money were the same as in the 1770 Act. Many of the expected nonloan payments in this emission's bills worked in the same fashion as for the previous emission. The administrating printer, commissioners, and clerk earned salaries for their work that were to be paid in the new bills (Archives of Maryland, v. 64, pp. 242, 244-8, 251-2). Three elements of the 1774 Act, however, made it unique.

The first unique element was how the printed bills were segmented between uses. In the 1770 Act, a set quantity of bills were to be initially emitted, while a small amount of them were held to the side to be exchanged for torn or defaced bills. The segmentation in the 1774 Act was more complex. The $\$ 480,000$ authorized was split three ways, with $\$ 266,666.67$ printed to be loaned out through the traditional land-bank method, $\$ 80,000$ kept in reserve for a number of contingency expenses, and $\$ 133,333.33$ held in reserve for the sole purpose of exchanging torn or defaced bills (Archives of Maryland, v. 64, p. 242; Behrens 1923, p. 55). The size of the fund held to exchange for worn and defaced bills increased significantly relative to the previous act, most likely as a result of how frequently such exchanges took place under the 1770 Act.

Having a separate reserve for contingency expenditures meant that the Maryland government would not have to tax their citizens to retrieve the bills needed to pay those expenses. Thus, the legislature could avoid creating separate taxes, such as that needed to repair the Stadt House as was the case in the 1770 Act. They could do this in part because the structure of the 1770 emission yielded funds at redemption in excess of what was needed to redeem the bills outstanding at that date. In effect, the legislature was extracting some of that forecasted surplus at redemption in the 1774 Act for spending now by using some bills for direct spending rather than for loaning out (and then re-loaning the interest earned).

The second unique element in the 1774 Act was a more equitable distribution of the bills 
available to be loaned out. The 1770 Act had placed caps on how much could be lent to a single borrower. Nothing, however, prevented a single county from borrowing all of the new bills. To spread the new paper money across the province, the 1774 Act, besides maintaining the individual borrowing caps from the 1770 Act, included a provision that capped the amount of bills that could be lent to the inhabitants of each county in the colony. ${ }^{6}$ The caps stayed in place for the first two months of the emission, the period of time based on data from the previous emission over which most, if not all, of the bills would be lent out. Each county's cap was set at a different amount, appearing to be done on the basis of population, so that the bills "may be distributed as equally and diffused as generally throughout the Province as may be” (Archives of Maryland, v. 64, p. 245).

The final unique element in the 1774 Act involved a provision regarding the conditional relending of bills received in payment. In the previous act, nothing prevented the commissioners from relending bills at any time up until the last year the bills were supposed to circulate. However, the 1774 Act included a special rule regarding relending. If the exchange rate between Spanish silver dollars and pounds sterling was above par (if a silver dollar received more than four shillings and six pence sterling in the marketplace), no more bills of credit were to be reloaned out of the office until that exchange rate matched or fell below that par rate (Archives of Maryland, v. 64, p. 250). The purpose of this rule is not well articulated in the literature. It did not control the value of Maryland's bills of credit, as the governing exchange rate in the rule was not between Maryland's bills of credit and specie but between one silver money (Spanish dollars) and another silver money (pounds sterling).

The rule appears to be an effort to prevent a fall in the real asset present value of

\footnotetext{
${ }^{6}$ County quotas had become a standard feature of some other colony's loan-office emissions of paper money earlier in the century, such as in New Jersey (Grubb 2013).
} 
current bills outstanding caused by an expected adverse currency conversion movement at redemption. The bills were denominated in Spanish silver dollars and were to be so redeemed at that face value at their legislatively designated redemption date. The act of redemption, however, used funds that were denominated in pounds sterling silver money. The Maryland legislature had sent the conversion of one silver money into another silver money for the purpose of redemption and printed that rate on the face of the bills (Newman 2008, pp. 171-3).

If the market rate of silver dollars to pounds sterling rose, then at the redemption conversion rate printed on Maryland's bills, the holder would be given pound sterling that would now be worth less than the silver dollar face value of the bill. Expecting a less than face value redemption of the bills due to this adverse movement in the currency conversion between these two silver monies, bill holders would reduce their estimated real asset present value of current bills and so reduce the bill's current market value. The special rule in the 1774 Act, therefore, was designed to prevent the commissioners from making new loans of paper money when the bills were losing value in the marketplace. This was not because the bills were depreciating due to some problem with the bills themselves, such as due to over issue, but because of adverse movements in the market exchange rates between different silver monies. Maryland's legislature did not want their subjects to erroneously associate a fall in the present value of the bills with an increase in the emission of bills, and so be confused over what was driving the current market value of the bills in terms of their real asset present value at redemption. All three unique elements in the 1774 Act, the special relending rule, the effort to spread the bills more evenly throughout the province, and the shifting of net earnings at redemption into a contingency fund for current use were all examples of Maryland's legislature learning from previous emissions and adapting their monetary system to enhance its performance and better meet their colony’s needs. 
At the end of the 1774 emission, the commissioners still held the same tasks before them as with the previous emission. First, they were to stop emitting and relending bills at the beginning of the final year of the emission span, i.e. on 10 April 1785. The principal payments on the loans were called in from April 10th to October 10th, and from 10 October 1785 to 10 April 1786, any bills of credit still outstanding could be redeemed for bills of exchange payable at the usual rate of four shillings and six pence pounds sterling per Spanish silver dollar printed on the face of each bill (Archives of Maryland, v. 64, p. 249).

\section{f. The Third Non-Legal-Tender Emission (1774): Quantitative Analysis}

In planning the emissions in the 1774 Act, the legislature set up a multi-part emission system. While some of the bills were nearly guaranteed to be emitted as the result of loans, the money for unassigned contingency expenses was unlikely to be spent in the first year of the emission. When the bills printed for contingency expenses were actually emitted into circulation is difficult to determine. The execution of the 1774 Act, along with the recordkeeping to accompany it, was much less precise than in previous years. The committee to inspect the loan office stated that, "by Reason of a multiplicity of Business now transacting in said Office and the want of Time your Committee have not been able this Session to Examine the Accounts of said Office” (Archives of Maryland, v. 64, p. 300). Unfortunately, this legislative session would be the last traditional session before the legislature resolved themselves into the first of many conventions designed specifically to manage the war effort. As such, estimating the amount of bills actually emitted during 1774 and 1775 is less exact than for the previous years.

On this basis, it is fair to assume that all \$266,666.67 in the 1774 Act designated to be emitted as loans were in fact emitted in 1774, just as the full amount of the 1770 emission was lent out within the first year. Both acts relied upon the same land bank structure. Additionally, 
the planned portion of the contingency expenses that were necessary to be paid in 1774 and 1775 for the bills to be emitted, as they were the salaries for the workers who executed the act, can be assumed to have been emitted in these years. Table 3 shows the actual application of the 1774 Act in terms of the flow of emissions over the first two years as it likely worked.

Out of the $\$ 80,000$ designated to pay contingency expenses, Table 3 counts only $\$ 4,000$ as being spent in 1774-5. The rest consisted of $\$ 58,450$ of unassigned contingency expense reserves. There is no evidence that these reserves were released for spending before 1776, and so they are not included in Table 3. The other assigned contingency funds were $\$ 2,670$ for post1775 clerk salaries, $\$ 6,880$ for post-1775 commissioner salaries, and $\$ 8,000$ for repairing the Fort Cumberland road. Again, these sums are not included in Table 3 because there is no evidence that they were released and emitted into circulation pre-1776.

Once again, the actual emissions for the 1774 Act estimated in Table 3 conflicts with that reported in the Historical Statistics of the U.S. (Carter 2006, v. 5, p. 693; Price 1977, p. 8). While \$480,000 in bills of credit were printed, only \$266,666.67 were designated for initial emission, and $\$ 80,000$ were set aside solely for contingency expenses. The last $\$ 133,333.33$ were to be used for exchanging torn and defaced bills for new bills, meaning that the cap on the emission was a maximum of $\$ 346,666.67$, not the $\$ 480,000$ which were printed and reported as emitted in the Historical Statistics of the U.S. One-for-one swaps of worn and ragged bills for new bills do not increase emissions or count toward the amount of bills outstanding or in circulation. While Ernst (1973, p. 369) and Greene and Jellison (1961, p. 494) get the maximum authorization correct, reporting a rounded authorization of $\$ 347,000$ and $\$ 346,667$, respectively, they do not report the amounts of this authorization that were actually emitted and outstanding over time. 
Table 3. Planned and Actual Emissions under the 1774 Paper Money Act, 1774-1775

\begin{tabular}{lcccrr}
\hline Year & Loans & $\begin{array}{c}\text { Commissioner } \\
\text { Salaries }\end{array}$ & $\begin{array}{l}\text { Clerk } \\
\text { Salary }\end{array}$ & $\begin{array}{l}\text { Printer } \\
\text { Salary }\end{array}$ & $\begin{array}{l}\text { 1774 Bills } \\
\text { Outstanding }\end{array}$ \\
\hline 1774 & $\$ 266,666.67$ & $\$ 1,040$ & $\$ 350$ & $\$ 1,500$ & $\$ 269,556.67$ \\
1775 & 0 & 800 & 310 & 0 & $270,666.67$ \\
\hline
\end{tabular}

Sources: See the text.

g. Total Bills Outstanding Each Year, 1767-1775, and Their Redemption Funding to 1786

Total bills outstanding and in circulation in any given year is the aggregate of those from the three paper money acts, namely the 1767,1770 , and 1774 Acts, that were in circulation each year. This aggregation, in face value, from 1767 to 1775 is presented in Table 4. Overall, the reconstruction of the data of Maryland's emissions of paper money shows that prior estimates in the literature are too high, based on what is reported in the Historical Statistics of the U.S. (Carter 2006, v. 5, p. 693; Price 1977, p. 8). From 1767 through 1769, the prior literature overstates the amount of bills in circulation by 11 to 12 percent, and from 1774 through 1775 by 33 percent. Thus, Table 4, and the prior analysis that comprises its construction, is a valuable corrective to the literature and a net new addition to scholarship in its own right. ${ }^{7}$

Table 5 provides an assessment of the redemption plans for the three non-legal-tender paper money acts. These are forecasted ideal values, as the numbers rest not only on the legislated plan for redemption, but on assumptions about realized actions between emission and redemption. The construction in Table 5 assumes that no one expected the Revolution, and that the expected dividend rate for the monies invested in the sinking fund stayed at 5 percent. It also assumes that each Act's emissions were carried out as legislated, and eventually to the maximum

\footnotetext{
7 Ernst (1973, pp. 168, 369) only reports bills outstanding for the years 1767, being $\$ 145,000$, and 1770 , being $\$ 500,000$. His estimates are off by only 9.1 and 7.2 percent, respectively, compared with Table 4.
} 
Table 4. Maryland Bills of Credit Outstanding Each Year, 1767-1775

\begin{tabular}{|c|c|c|c|c|c|c|}
\hline Year & $\begin{array}{c}\text { From the } \\
1767 \text { Act } \\
{\left[\mathrm{M}_{1}\right]}\end{array}$ & $\begin{array}{c}\text { From the } \\
1770 \text { Act } \\
{\left[\mathrm{M}_{2}\right]}\end{array}$ & $\begin{array}{c}\text { From the } \\
1774 \text { Act } \\
{\left[\mathrm{M}_{3}\right]}\end{array}$ & $\begin{array}{c}(\mathrm{A}) \\
\text { Total } \\
1767-1775 \\
{[\mathrm{MT}]}\end{array}$ & $\begin{array}{l}\quad(\mathrm{B}) \\
\text { Historical } \\
\text { Statistics } \\
\text { Totals }\end{array}$ & $\begin{array}{l}\text { Percentage } \\
\text { Difference } \\
{[(\mathrm{B}-\mathrm{A}) / \mathrm{A}]}\end{array}$ \\
\hline 1767 & $\$ 156,267.00$ & & & $\$ 156,267.00$ & $\$ 173,700.00$ & $11.16 \%$ \\
\hline 1768 & $156,267.00$ & & & $156,267.00$ & $173,700.00$ & 11.16 \\
\hline 1769 & $154,802.61$ & & & $154,802.61$ & $173,700.00$ & 12.21 \\
\hline 1770 & $158,214.62$ & $\$ 300,000.00$ & & $458,214.62$ & $491,700.00$ & 7.31 \\
\hline 1771 & $158,214.62$ & $300,000.00$ & & $458,214.62$ & $491,700.00$ & 7.31 \\
\hline 1772 & $158,214.62$ & $300,000.00$ & & $458,214.62$ & $491,700.00$ & 7.31 \\
\hline 1773 & $160,094.02$ & $300,000.00$ & & $460,094.02$ & $491,700.00$ & 6.87 \\
\hline 1774 & $160,094.02$ & $300,000.00$ & $\$ 269,556.67$ & $729,650.69$ & $971,700.00$ & 33.17 \\
\hline 1775 & $160,094.02$ & $300,000.00$ & $270,666.67$ & 730,760.69 & $971,700.00$ & 32.97 \\
\hline
\end{tabular}

Sources: Tables 1, 2, and 3; Carter (2006, v. 5, p. 693); Price (1977, p. 8).

Notes: Excludes new emissions for the year 1775, see fn. 12. Bracketed numbers, e.g. $\mathrm{M}_{1}$, count the non-legal-tender emissions, namely the face value of individual paper money supplies from each separate emission's Act. MT = total bills outstanding in face value each year, i.e. the total Maryland paper money supply currently in circulation.

amount authorized to be emitted and allowed to be re-loaned by their respective redemption dates. It also assumes that loans and interest were paid as planned, or their defaulted amounts were made up by the timely confiscation of the defaulter's property. In addition, for easy comparability, all values in Table 5 are converted into Spanish silver dollars at the par or maturity redemption rate set for Maryland bills of credit, namely $\$ 4.4444=1 £_{\mathrm{s}}$.

Table 5 shows that the planned redemption structures legislated, with reasonably forecasted outcomes from the perspective of 1767-1774, and setting aside the Revolution, were sound. Redemption at face value as promised in the 1767,1770 , and 1774 Acts was easily achievable. As such, a priori, subjects should have attached no default risk to these bills of credit. This conclusion is important for the modeling analysis that follows, as the size of the default risk discount attached to the bills cannot be independently measured. Assuming it is close to zero improves the interpretive power of the model and the empirical analysis that follows. 
Table 5.

Forecasted Ideal Redemption Plans for the 1767, 1770, and 1774 Emissions, 1766-1787

\begin{tabular}{|c|c|c|c|c|c|c|c|}
\hline \multirow[b]{2}{*}{ Year } & \multicolumn{3}{|c|}{ THE SINKING FUND } & \multicolumn{2}{|c|}{ THE 1770 EMISSION } & \multicolumn{2}{|c|}{ THE 1774 EMISSION } \\
\hline & $\begin{array}{l}\text { Total } \\
\text { Amount } \\
\text { in the } \\
\text { Fund }\end{array}$ & $\begin{array}{c}5 \% \\
\text { Annual } \\
\text { Dividend } \\
\text { Additions }\end{array}$ & $\begin{array}{l}\text { Funds } \\
\text { Withdrawn, } \\
\text { Redemptions, } \\
\text { and Additions }\end{array}$ & $\begin{array}{l}\text { Total } \\
\text { Loan } \\
\text { Principal } \\
\text { Outstanding }\end{array}$ & $\begin{array}{l}\text { 4\% Interest } \\
\text { Earned } \\
\text { and then } \\
\text { Loaned Out }\end{array}$ & $\begin{array}{l}\text { Total } \\
\text { Loan } \\
\text { Principal } \\
\text { Outstanding }\end{array}$ & $\begin{array}{l}\text { 4\% Interest } \\
\text { Earned } \\
\text { and then } \\
\text { Loaned Out }\end{array}$ \\
\hline & $\$$ & $\$$ & $\$$ & $\$$ & $\$$ & $\$$ & $\$$ \\
\hline 1766 & 159,998 & 8,000 & & & & & \\
\hline 1767 & 167,998 & 8,400 & & & & & \\
\hline 1768 & 176,398 & 8,820 & & & & & \\
\hline 1769 & 185,218 & 7,039 & $-44,444$ & & & & \\
\hline 1770 & 147,813 & 7,391 & (for use of & 300,000 & 12,000 & & \\
\hline 1771 & 155,204 & 7,760 & the Province) & 312,000 & 12,480 & & \\
\hline 1772 & 162,964 & 8,148 & & 324,480 & 12,979 & & \\
\hline 1773 & 171,112 & 8,556 & & 337,459 & 13,498 & & \\
\hline 1774 & 179,667 & 8,983 & & 350,958 & 14,038 & 266,667 & $(10,667)^{a}$ \\
\hline 1775 & 188,651 & 9,433 & & 364,996 & 14,600 & 266,667 & $(10,667)^{a}$ \\
\hline 1776 & 198,083 & 9,904 & & 379,596 & 15,184 & 266,667 & $(10,667)^{a}$ \\
\hline 1777 & 207,988 & 10,399 & & 394,780 & 15,791 & 266,667 & $(10,667)^{c}$ \\
\hline 1778 & 218,387 & 10,919 & $-173,733^{b}$ & 410,571 & 16,423 & 266,667 & 10,667 \\
\hline 1779 & 44,654 & 2,779 & (1767 Emission & 426,994 & 17,080 & 277,333 & 11,093 \\
\hline 1780 & 55,573 & 2,918 & Redemption) & 444,073 & 17,763 & 288,427 & 11,537 \\
\hline 1781 & 58,352 & 3,063 & & 461,836 & 18,473 & 299,964 & 11,999 \\
\hline 1782 & 241,579 & 12,079 & $+180,310^{\mathrm{C}}$ & $-300,000$ & $(+18,473)$ & 311,962 & 12,478 \\
\hline 1783 & 253,658 & 12,683 & (Excess from 1770 & (Redeemed) & & 324,441 & 12,978 \\
\hline 1784 & 266,341 & 13,317 & Emission Redempt & on) & & 337,418 & 13,497 \\
\hline 1785 & 279,658 & 13,983 & & & & 350,915 & 14,037 \\
\hline 1786 & 311,926 & 15,596 & $+18,285^{\mathrm{d}}$ & & & $-346,667$ & $(+14,037)$ \\
\hline 1787 & 327,522 & 16,376 & (Excess from 1774 & Emission Rede & mption) & (Redeemed) & \\
\hline
\end{tabular}

Sources: See the text and Tables 1, 2, 3, and 4; Archives of Maryland (v. 14, pp. 254-5, 390; v. 59, 183-4; v. 61, p. ci; v. 63, p. 35); Price (1977, p. 7).

Notes: The maximum number of bills that could be emitted under each emission act are assumed to have been eventually emitted and were outstanding at the required redemption date set by the bill's respective legislative act. All values are face values and converted to Spanish silver dollars at the face value redemption rate set by the Maryland legislature, namely $4.4444 \$=1 \varepsilon_{s}$.

${ }^{\mathrm{a}}$ Interest earnings diverted to funding the Seminary of Learning (Archives of Maryland, v. 63, p. 35).

${ }^{\mathrm{b}}$ Redemption was executed at the end of 1778.

${ }^{\mathrm{c}}$ Loans were called in during 1781, but redemption went into early 1782.

${ }^{\mathrm{d}}$ Loans were called in during 1785, but redemption went into early 1786.

The 1767 bills were to be redeemed from the sinking fund. The sinking fund grew at an expected annual rate of 5 percent from re-invested dividends. No new tax revenues were added to the sinking fund in this period. Table 5 show that this growth rate from the initial level of the fund in 1766 was enough to fully redeem all 1767 bills at their maximum authorized amount at 
the rate promised, even after the Maryland legislature withdrew money from the sinking fund in 1769. After redemption in 1778 , the fund was expected to still have a balance of $\$ 44,654$.

The 1770 and 1774 Acts were designed to redeem themselves through the cancellation of loan principal at their respective redemption dates (loan principal payoff dates). Table 5 assumes that all annual interest payments were made in the respective Act's bills of credit, which were then re-loaned as the Acts required. This relending increased the loan principal outstanding beyond the amount of bills in each Act designated for lending out through the land bank. The exception is for the first four years of interest under the 1774 Act, which is assumed to have been designated to fund the Seminary of Learning. This kept the bills in circulation but did not add to the outstanding loan principal in these years. Table 5 shows that the relending process in the 1770 and 1774 Acts yielded more principal and interest to be called in than there were bills to be redeemed. Thus, both Acts more than redeemed themselves. The excess funds, which would have been paid in specie, are assumed to have been added to the sinking fund.

Under the assumptions made, in the year after the last redemption of these paper bills (1787), the Maryland government would have a net positive fund of $\$ 327,522$ at its disposal. The values in Table 5 are a worst case scenario regarding the prospects of successful redemption, again ignoring the Revolution. The numbers assume the maximum amount of bills in circulation. In addition, if some annual loan interest in the 1770 and 1774 Acts was paid in specie rather than bills, and so could not be re-loaned, that would make redemption more certain. While the loan principal outstanding would not have grown as much as shown in Table 5, assuming the specie received in interest payments was placed in the sinking fund means that fund would have grown by an even greater amount, at a 5 percent dividend rate versus a 4 percent loan interest rate, than the loan principal over time. Under such an outcome there would have been an even greater total 
fund, sinking fund plus loan principal called in, for redemption at the respective redemption dates than shown in Table 5. No matter how you slice it, redemption as promised was likely forecasted by subjects as certain, again ignoring the possibility of Revolution.

\section{Estimating the Liquidity Premium to Maryland's Non-Legal-Tender Bills of Credit}

Did these non-legal-tender bills function as "money," as opposed to just being tradable bonds? To determine this, a model is presented for measuring the liquidity premium of these bills. Liquidity is the measure of how quickly an asset can be turned into real money (specie). When a debt instrument, with future contractual real money cash flows, trades at a value above the discounted present value of those cash flows, it is being traded at a premium. If Maryland's post-1764 bills traded at a premium, then this liquidity premium measures the bills' “moneyness" value - their value beyond that as just tradable bonds because the bills were being used as the preferred medium of exchange. After discussing the model, the construction of the data needed to make the model operational is presented.

\section{a. The Model}

The market exchange value (MEV) of Maryland's bills of credit is decomposed into its component parts. MEV equals its expected asset present value (APV), i.e. its value as just another non-money real barter asset, minus a risk discount (RD) that captures any expected default risk connected with these bills, plus its liquidity premium (LP) that encompasses its “moneyness" value, i.e. its extra value as a transacting medium, see equation (1). ${ }^{8}$ Positive values for LP measure the willingness of the public to pay a premium above the bills' expected real asset present value because it serves as a more convenient transacting medium than the next

\footnotetext{
8 This decomposition is consistent with the model of paper money laid out by Benjamin Franklin in a tract written in Philadelphia in 1729 (Labaree 1959, v. 1, p. 153), by Gouverneur Morris in a tract written in Philadelphia in 1778 (Barlow 2012, pp. 73-6), and by James Madison in a tract written in 1779 (Hutchinson and Rachal 1962, v. 1, pp. 305-6). As such, it can be considered consistent with how colonial contemporaries thought about their paper money.
} 
best barter alternative. A positive LP means the bills have some fiat currency attributes. The extent that colonial paper money functioned as a real asset money (APV/MEV)t versus as a fiat currency $(\mathrm{LP} / \mathrm{MEV})_{\mathrm{t}}$ is disentangled by the decomposition exercise in equation (1).

$$
\mathrm{MEV}_{\mathrm{t}}=(\mathrm{APV}-\mathrm{RD})_{\mathrm{t}}+\mathrm{LP}_{\mathrm{t}}
$$

For a pure fiat currency, by definition, $\mathrm{MEV} \approx \mathrm{LP}$ and its $\mathrm{APV} \approx 0$. Whereas, for a pure outside real commodity, or real asset, money produced in an open-access competitive market, such as specie in the form of bullion or plate in the eighteenth-century transatlantic economy, arbitrage yields $\mathrm{MEV} \approx \mathrm{APV}$, leaving its $\mathrm{LP} \approx 0$ in long-run equilibrium. Somewhere between these pure cases resides the local paper monies used by colonial societies. If the long-run development of a society is thought of as transitioning from a pure commodity toward a pure fiat money, measuring where that society's money is on that evolutionary spectrum informs us about the level of that society's development and the state of its monetary institutions (Redish 1993). The approach in equation (1) is applicable to under-monetized colonial economies dominated by open external trade under a periphery-versus-core political economy trading structure (Grubb 2012b). ${ }^{9}$ Thus, besides the American colonies, it may prove useful for studying the monetary regimes of other under-monetized, developing, and colonially constrained economies.

Empirical measurement is the difficult aspect of applying this approach. While MEV can be measured using data on the bills' exchange rates to real money, $\mathrm{RD}$ and LP cannot be independently measured. In addition, APV does not have an obvious data construct. Conceptually, APV is a counterfactual value, namely the value of the bill when not used as a money. Given that the bills were used as money, constructing this counterfactual and disentangling it from MEV requires some effort.

\footnotetext{
${ }^{9}$ Rousseau (2006) argues that even with paper money the colonies remained under-monetized.
} 
Fortunately, as shown above, Maryland's bills were structured as zero-coupon bonds, similar to today's U.S. savings bonds, except they were transferable. Given expected maturity dates, payoff values, and an appropriate interest rate, the APV of these bills as non-money tradable debt instruments can be calculated independent of their MEV as a simple rational bond pricing exercise. Unfortunately, no time-series of market generated interest rates for any class of assets currently exists for colonial America. Thus, some clever empirical analysis must be employed to make the decomposition exercise in equation (1) operational. Two different methods are employed here.

The first method assumes that $\mathrm{LP}=0$ so that MEV measures the spot market value of these bills as non-money bonds. Given the expected redemption structure of the bills, the interest rate $\left(r^{*}\right)$ that makes $\mathrm{MEV}_{\mathrm{t}}=[\mathrm{APV}-\mathrm{RD}]_{\mathrm{t}}$ is calculated. If in fact $\mathrm{LP}=0$, then $r^{*}$ represents the first time-series of market generated interest rates created for any class of assets in colonial America. If $r^{*}$ is within the normal range of interest rates mentioned in the colonial literature, then the proposition that the bills are simply barter assets with no special "moneyness" value or fiat currency attributes cannot be rejected. If $r^{*}$ is relatively high, then nothing changes from the above conclusion except that now $\mathrm{RD}>0$, namely the bills are also relatively risky non-money bonds. If, however, $r *$ is relatively low, then the proposition that $\mathrm{RD} \approx 0$ and $\mathrm{LP}>0$, namely that the bills have some "moneyness" value and are functioning to some degree as a fiat currency, cannot be rejected. The extent that $r^{*}$ is outside the normal range measures the extent that $\mathrm{RD}>$ 0 when $r^{*}$ is relatively high, and the extent that $\mathrm{LP}>0$ when $r^{*}$ is relatively low.

The second method takes a range of long-run normal interest rates $(r)$ gleaned from the colonial literature and assumes they hold for assessing the present value of assets net of default risk. These interest rates are used to calculate the APV of Maryland's bills of credit independent 
of their MEV. Moving the variables that can be independently measured to the left-hand side and the variables that cannot be independently measured to the right-hand side yields equation (2).

$$
(\mathrm{MEV}-\mathrm{APV})_{\mathrm{t}}=(\mathrm{LP}-\mathrm{RD})_{\mathrm{t}}
$$

In terms of proportions, the ratio (APV/MEV) measures how much of $\mathrm{MEV}$ is accounted for by APV with the residual share being accounted for by (LP - RD) . The gap between MEV and APV, under certainty of redemption at face value on time as legislated, i.e. given $\mathrm{RD} \approx 0$, measures the existence and size of the LP of Maryland's paper money. Finding LP > 0 in this second method is the same as finding a below normal $r^{*}$ in the first method.

One reason for applying this second method to colonial Maryland is that, a priori, that colony’s paper money should experience no RD. Maryland had established a track record of redeeming its bills at face value on time as legislatively promised. It also maintained a sinking fund of real assets with more than sufficient funds to redeem the bills as legislatively promised (Behrens 1923, Smith 1985). Setting aside forecasted risks associated with the future Revolution, there was little default risk to holding Maryland bills of credit. Therefore, the present value of a bill, unadjusted for expected default risk, should capture all its non-money real asset present value. Because RD is expected to be minimal, equation (2) primarily measures LP.

\section{b. The Data}

To make the model operational, data on MEV, APV, and $r^{*}$ for 1767 through 1775 are constructed. MEV is constructed using the exchange rates between Maryland paper currency and pounds sterling — pounds sterling being a silver or real money. These exchange rates are reported as so many Maryland paper bills measured in terms of “Maryland hard currency pounds” needed to purchase one pound sterling in the form of a bill of exchange payable in London. Maryland's bills of credit in this period, however, were denominated in Spanish silver dollars and referred to 
as paper currency (Newman 2008, pp. 171-3). According to McCusker (1978, p. 194), the exchange rate between Maryland paper currency and Maryland hard currency was 1 to 1.25 . The second column in Table 6 uses this conversion rate to calculate a preliminary version of MEV, expressed as a percentage of face value, namely 125 is divided by the exchange rates reported in McCusker (1978, p. 199).

This preliminary version of MEV is refined to account for additional costs. The exchange rates reported are for bills of credit converted into bills of exchange and then shipped to London where they were liquidated into pounds sterling or their specie equivalent. Considerable transaction costs, in terms of time and money, must be taken into account to get a spot market exchange rate to specie in Maryland. These transaction costs are estimated to be about 7.09 percent of the face value of the bills of credit (Grubb 2014). ${ }^{10}$ As such, the effective "on the spot in Maryland" par or face value exchange rate between Maryland paper currency and Maryland hard currency is 1 to 1.1614. The third column in Table 6 uses this adjusted conversion rate to calculate the final version of MEV, expressed as a percentage of the bill's face value, namely 116.14 is divided by the exchange rates reported in McCusker (1978, p. 199).

To measure the bills’ APV, given their redemption (maturity) structures, a present value calculation must be performed. As discussed above, Maryland set the redemption for each nonlegal-tender emission to be 12 years after its initial emission year (11 years for the 1767 emission). ${ }^{11}$ No redemption would take place before the period designated for the redemption of

\footnotetext{
10 See Grubb (2014). The Boston Evening Post, 25 October 1773, estimated the cost of shipping specie between the colonies and London at 6 percent, which was comprised of 2.5 percent for insurance and brokerage, 2.5 percent commissions, and 1 percent for freight (Brock 1992, pp. 74, 124). Adding the opportunity cost of time, i.e. timediscounting, to his 6 percent raises that cost to approximately the rate estimated in Grubb (2014) of 7.09 percent. ${ }^{11}$ See also Price (1977, p. 8). Most colonies had long prorated redemption windows, such as $1 / 12$ of a given emission redeemed each year over a 12 year period (Grubb 2012a). By contrast, Maryland used an emission specific one-year redemption point per major emission. The exception being two one-year redemption points for the 1733 emission, i.e. one-third redeemed in 1748 and two-thirds redeemed in 1764 (Behrens 1923; Brock 1975, pp. 99-106; Smith 1985, pp. 1,199-1,208).
} 
Table 6. MEV, APV, and $r^{*}$ Data Estimates, 1767-1775

\begin{tabular}{|c|c|c|c|c|c|c|}
\hline Year & $\begin{array}{l}\text { Unadjusted Exchange } \\
\text { Rate as a Percentage } \\
\text { of Face Value }\end{array}$ & MEV & $r^{*}$ & $\begin{array}{l}\mathrm{APV}_{4} \\
\text { at } \\
4 \%\end{array}$ & $\begin{array}{l}\mathrm{APV}_{6} \\
\text { at } \\
6 \%\end{array}$ & $\begin{array}{l}\mathrm{APV}_{8} \\
\text { at } \\
8 \%\end{array}$ \\
\hline & $\%$ & $\%$ & $\%$ & $\%$ & $\%$ & $\%$ \\
\hline 1767 & 75.95 & 70.56 & 3.17 & 64.40 & 51.69 & 41.48 \\
\hline 1768 & 75.79 & 70.42 & 3.51 & 67.03 & 54.88 & 44.93 \\
\hline 1769 & 77.79 & 72.28 & 3.61 & 69.77 & 58.27 & 48.68 \\
\hline 1770 & 82.77 & 76.90 & 2.48 & 65.59 & 53.23 & 43.28 \\
\hline 1771 & 77.24 & 71.76 & 3.47 & 68.26 & 56.53 & 46.88 \\
\hline 1772 & 78.80 & 73.21 & 3.65 & 71.05 & 60.02 & 50.78 \\
\hline 1773 & 75.70 & 70.33 & 4.68 & 73.98 & 63.78 & 55.06 \\
\hline 1774 & 74.81 & 69.50 & 4.33 & 71.41 & 60.68 & 51.76 \\
\hline 1775 & 79.78 & 74.12 & 4.04 & 74.31 & 64.42 & 56.05 \\
\hline \multicolumn{7}{|l|}{ Yearly } \\
\hline Average & 77.63 & 72.12 & 3.66 & 69.53 & 58.17 & 48.77 \\
\hline
\end{tabular}

Sources: See the text and Grubb (2014); McCusker (1978, pp. 194, 199).

Notes: New paper money emissions in 1775 are not incorporated. See fn. 12.

the bills for each respective emission. Given that new emissions occurred before the redemption of prior emissions, bills from different emissions were outstanding at the same time. Because the bills were dated (Newman 2008, pp. 171-3), the public knew when each bill would be redeemed.

The exchange rate evidence used to construct MEV, however, does not distinguish between bills of different emissions. Therefore, the APV for a given year is taken as that for the representative bill outstanding, i.e. for a random draw of bills, for that year. Given the staggered and overlapping emission-redemption structure, a weighted average of the three emissions (1767, 1770, and 1774) and their respective redemption dates, are used to calculate the APV of this representative bill for each year from 1767 through $1775 .{ }^{12}$

Present value calculations require an interest rate $(r)$. Appropriate market generated data

\footnotetext{
12 The new emissions for 1775 are not incorporated in any calculations in this paper. The new emissions for 1775 were not authorized until July of that year and did not go into circulation until near the end of that year. Thus, ignoring the new emissions in 1775 for calculating the values for 1775 in this paper is appropriate. See Behrens (1923, pp. 59-60); Newman (2008, pp. 174-5).
} 
on $r$ for doing present value calculations are lacking. Two methods are used to overcome this lack of data. First, under the assumption that LP $=0$, an imputed $r^{*}$ is calculated, namely the interest rate that makes $\mathrm{MEV}_{\mathrm{t}}=\mathrm{APV}_{\mathrm{t}}$. This calculation entails selecting $r^{*}$ such that $\mathrm{MEV}_{\mathrm{t}}=$ $\sum_{i=1}^{3}\left(\mathrm{M}_{i t} / \mathrm{MT}_{t}\right) e^{-r *(R Y i-t)}$, where $i=$ the sequence of the three non-legal-tender emissions (1767, 1770, 1774, respectively), $t=$ the specific year in question, $M=$ the amount of bills currently outstanding at face value from each emission, MT = total bills currently outstanding from all three emissions combined at face value, and $R Y=$ the designated redemption year. Table 6 reports the $r^{*}$ for each year that satisfies this equation.

Second, given the long-run interest rates considered normal in the colonial literature, the counterfactual expected APV of a representative Maryland bill currently outstanding as just a non-money tradable bond net of default risk, expressed as a percentage of its face value, is calculated, i.e. $\mathrm{APV}_{\mathrm{t}}=\sum_{\mathrm{i}=1}{ }^{3}\left(\mathrm{M}_{i t} / \mathrm{MT}_{\mathrm{t}}\right) e^{-r^{*}(R Y i-t)}$, where $r$ is the long-run interest rate or opportunity cost of capital. The long-run interest rate considered to be "normal” was around 6 percent. $^{13}$ Given uncertainly over the exact rate, a range of interest rates, namely 4, 6, and 8 percent or 2 percentage points on either side of the normal 6 percent rate, are used. The APV for these three rates are reported in Table 6. The loans of paper money in the 1770 and 1774 Acts were at 4 percent, so rates could not be below that rate in equilibrium and still have positive

\footnotetext{
${ }^{13}$ From the 1760s through the 1790s, an interest rate of 6 percent in mid-America appears most common, see Brock (1975, pp. 260, 328, 332, 435, 462); Davis (1964, v. 1, p. 326; v. 2, pp. 38, 68, 83, 99-100, 315, 321; v. 3, p. 168; v. 4); Nettels (1934, p. 267). Six percent was the rate used by the national government for loans between 1776 and 1790, and the most common rate mentioned throughout this period, see Barlow (2012, pp. 110, 125, 128); Elliot (1843); Ferguson (1988, v. 7, p. 547); Homer and Sylla (1991, pp. 274-313); Hutchinson and Rachel (1962, v. 1, p. 308); Journals of the Continental Congress (v. 2, pp. 25-6; v. 6, p. 1037; v. 7, pp. 102-3, 158, 168; v. 8, pp. 725-6; v. 9, pp. 955, 989; v. 10, p. 59; v. 11, p. 416; v. 12, pp. 929-30, 932, 1074, 1256; v. 13, pp. 112, 141, 146-7, 441, 497; v. 14, pp. 717, 720, 731-2, 783, 820, 901; v. 15, pp. 1147, 1197, 1210, 1225, 1245-6, 1288, 1319,1405; v. 16, pp. 264-5, 288; v. 17, pp. 464, 568, 804; v. 18, p. 1017; v. 19, pp. 6, 167; v. 21, p. 903; v. 23, p. 831; v. 24, p. 39; v. 26, p. 32; v. 27, pp. 395-6); Pennsylvania Gazette (30 April; 21 and 28 May; 25 June; 2, 16, and 23 July 1777); Puls (2008, p. 181); Smith (1979, v. 4, p. 295; 1980, v. 6, pp. 117-8, 212-3, 228-9, 238-9, 245, 252, 259-62, 270, 277 , 295, 346, 368, 372, 386, 400-1, 404; 1981, v. 7, pp. 524, 581, 617, 623, 635, 642-3; 1981, v. 8, p. 25; 1983, v. 10, p. 205; 1985, v. 11, pp. 94, 137-8, 361; 1986, v. 13, pp. 132, 604-5; 1987, v. 14, pp. 51, 463, 500; 1988, v. 15, pp. 377, 396; 1989, v. 16, pp. 307-8, 490, 531; 1990, v. 17, p. 365; 1992, v. 19, p. 139; 1994, v. 21, p. 467).
} 
loans taken out by rational borrowers.

\section{Evaluating the Liquidity Premium to Maryland's Non-Legal-Tender Bills of Credit}

a. Imputed $r^{*}$ for $M E V=A P V$ with $L P=0$

Table 6 reports $r^{*}$ for 1767 through 1775. In all years, this rate is below, and sometimes considerably below, what is commonly taken as the normal market interest rate, or opportunity cost of capital, in colonial America. Therefore, the proposition that $\mathrm{RD} \approx 0$ and LP $>0$, namely that Maryland’s non-legal-tender bills had some “moneyness” value and were functioning to some degree as a fiat currency, cannot be rejected.

These below-normal $r^{*}$ rates do not represent the market interest rate being driven down by the emission of Maryland paper money. After 1770, the emission of Maryland paper money was largely through a land-bank mechanism where subjects borrowed paper money from the colonial treasury at 4 percent interest. It would be irrational for subjects to continue borrowing new paper money to put into circulation at 4 percent when the market rate was at or below 4 percent. Finally, no contemporary writer, or any other evidence, indicates that market interest rates were as low as $r^{*}$ in these years. Therefore, the below-normal $r^{*}$ rates represent something other than a relatively low opportunity cost of capital driven by the emission of paper money. In other words, the proposition that LP > 0 cannot be rejected. The relative size and determinants of this LP will be addressed in the following sections.

Because $r *$ is not measuring the true opportunity costs of capital, but instead is reflecting LP $>0$, it cannot be used to calculate present values. Thus, the second method that uses the range of normal market interest rates in the colonial economy will be used to calculate APV. The outcome of this second method is used throughout the rest of the paper. The gap between MEV and APV found in the second method has the same interpretation as below-normal $r^{*}$ values in 
the first method, namely below-normal $r^{*}$ values are the same as (LP - RD) $>0$.

\section{b. Tracking the Levels of MEV and APV of Maryland's Non-Legal-Tender Paper Money}

Using the data in Table 6, Figure 1 compares the levels over time of MEV and APV, as a percentage of face value, when APV is discounted at 4, 6, and 8 percent. For the entire period from 1767 through 1775, using the best-guess 6 percent discount rate, APV accounts for 81 percent of MEV, leaving (LP - RD) to account for 19 percent of MEV. ${ }^{14}$ While the value of Maryland's non-legal-tender bills of credit was primarily due to their value as non-money tradable real-asset bonds, they did possess some LP or "moneyness" value. Some erosion in this (MEV - APV) gap, however, occurred over time. Using the 6 percent discount rate, (LP - RD) declined from 31 percent of MEV in 1770 to 13.1 percent of MEV by 1775.

One explanation of this declining (LP - RD) after 1771 is that Maryland paper money holders feared that some of their bills would not be paid off at redemption given the rising tensions pointing toward a revolutionary break with the mother country. The sinking fund out of which the 1767 bills were to be redeemed would be in the hands of the enemy if hostilities broke out (Behrens 1923, pp. 56-8, 88-94; Price 1977, p. 8). While RD might be safely assumed to be zero before 1773 due to Maryland's redemption track record, this assumption might not hold in the years right before the Revolution. Some positive RD in these years may account for the erosion in the positive value of (LP - RD) as measured by the (MEV - APV) gap.

In conclusion, colonial Maryland's non-legal-tender paper money was not predominantly a fiat currency. It was overwhelmingly a real asset barter bond or real asset money. Its real asset present value explains the vast majority of its market value. Still, a sizeable portion of its value was comprised of a liquidity premium. In addition, Figure 1 shows no overall depreciation of

\footnotetext{
14 This percentage division of MEV between APV and (LP - RD) is almost identical to the average division found for New Jersey's legal tender bills of credit from 1709 through 1774 (Grubb 2014). This similarity is consistent with no value or performance difference between legal tender and non-legal-tender bills of credit.
} 


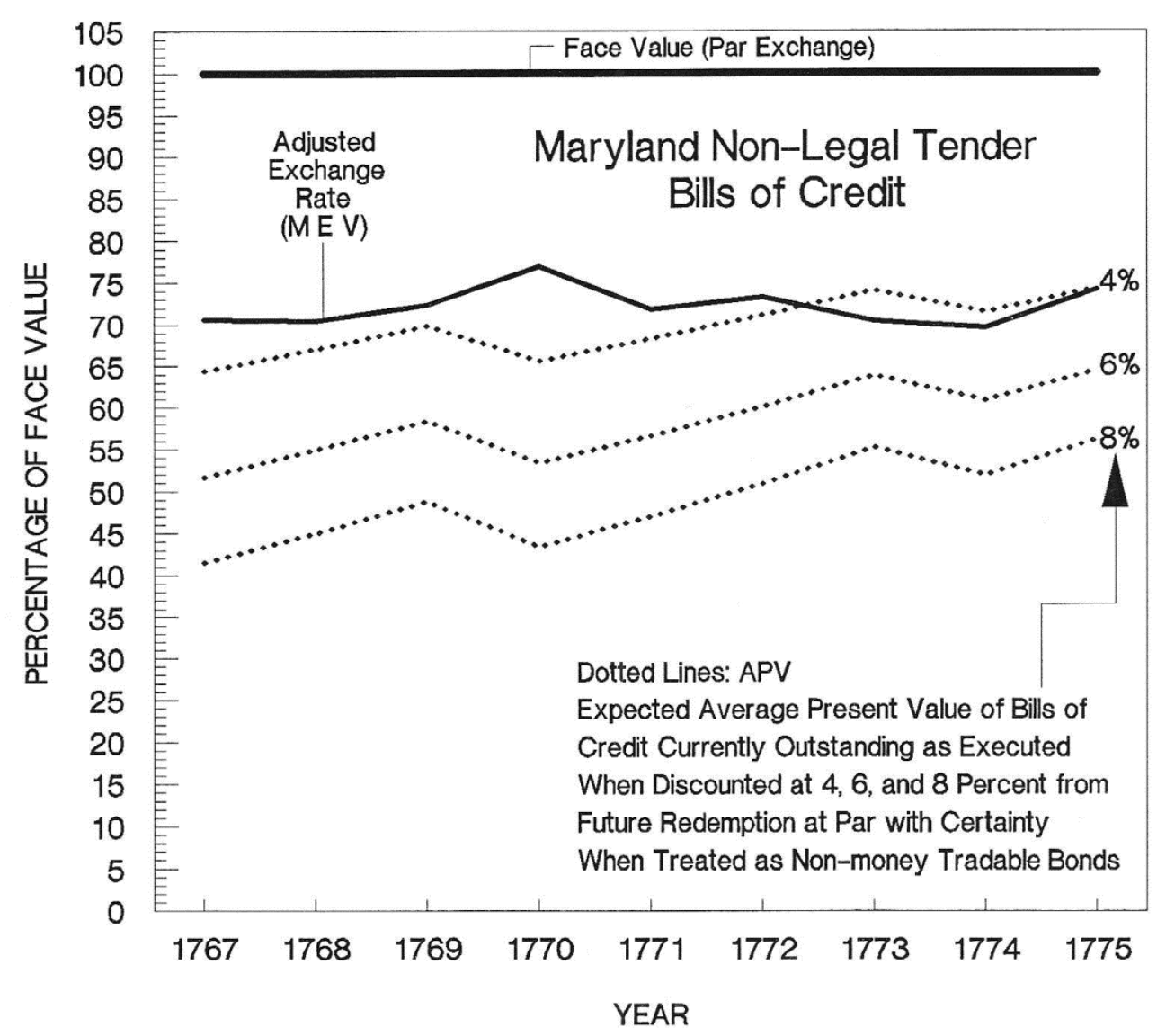
$\begin{array}{ll}\text { Figure } 1 & \text { Average Adjusted Exchange Rate (MEV) and Average Expected } \\ \text { Present Values (APV) of Maryland's Paper Money, 1767-1775 }\end{array}$

Source: Table 6.

Notes: See text for discussion. New paper money emissions in 1775 are not incorporated. See fn. 12.

Maryland's paper money, depreciation here meaning a loss of asset principal as measured in present value terms. The fact that Maryland's paper money traded below its face value, i.e. that its MEV was less than 100 percent of face or par value, does not mean that it had depreciated or that inflation had eroded its real asset value. The difference between the bills' face value and their MEV was overwhelmingly due to time-discounting and not depreciation. The existence of an overall positive (LP - RD) indicates that the bills actually traded at an appreciated value, namely at a value above their real asset present value.

Scholars both past and present, when evaluating colonial paper monies, have largely 
confused time-discounting with depreciation. This confusion springs, in part, from the erroneous assumption that colonial paper monies were fiat currencies. They simply missed the fact that these paper bills were zero-coupon bonds with their MEV closely tracking their non-money realasset present value. This finding radically changes most of the received history of colonial monetary performance regarding the presumed inflationary tendencies of these paper monies.

\section{Statistical Analysis of the Determinants of the Liquidity Premium}

The LP attached to Maryland’s non-legal-tender bills of credit influenced the bills’ market value. Governor Sharpe and the Maryland legislature, when initially designing these nonlegal-tender paper money emissions, hoped the bills would work as a substitute for real money. The LP attached to these bills is a measure of how far these bills acquired that property of “moneyness” beyond serving as just tradable non-money bonds. Equation (2) shows that (MEV $A P V)_{t}=(L P-R D)_{t}$. Thus if $R_{t}=0$, then $(M E V-A P V)_{t}=L_{t}$. The existence and determinants of LP as measured by the (MEV - APV) gap are explored with two statistical tests.

First, difference-in-means tests ([LP - RD] $=0$ vs. $[\mathrm{LP}-\mathrm{RD}] \neq 0)$, using the 4,6 , and 8 percent discount rates, are performed. These results, reported in Table 7 , are mixed. The $\left(\mathrm{LP}_{6}\right.$ $\mathrm{RD})$ and ( $\left.\mathrm{LP}_{8}-\mathrm{RD}\right)$ tests are positive and statistically significant, indicating that if the true market interest rate was 6 or 8 percent the bills contained a noticeable LP. At 4 percent, the bills do not have a statistically significant LP. However, 4 percent was the minimum rate, because it is the same rate that Maryland used to incentivize the borrowing of paper money by its subjects. Given that $\left(\mathrm{LP}_{6}-\mathrm{RD}\right)$ and $\left(\mathrm{LP}_{8}-\mathrm{RD}\right)$ are statistically significant, an additional test is performed to explore the determinants of (LP - RD). Table 8 reports the results of regressing $\left(\mathrm{LP}_{6}-\mathrm{RD}\right)$ and $\left(\mathrm{LP}_{8}-\mathrm{RD}\right)$ on time and the per capita face value amount of Maryland paper money outstanding. The results show that (LP - RD) is negatively associated with time and positively associated with 
Table 7. Means Test for Liquidity Premium Data

\begin{tabular}{lrl}
\hline Test & \multicolumn{1}{c}{$t$} & $p$-value \\
\hline$\left(\mathrm{LP}_{8}-\mathrm{RD}\right)=0$ vs. $\left(\mathrm{LP}_{8}-\mathrm{RD}\right) \neq 0$ & 12.04 & 0.000 \\
$\left(\mathrm{LP}_{6}-\mathrm{RD}\right)=0$ vs. $\left(\mathrm{LP}_{6}-\mathrm{RD}\right) \neq 0$ & 7.94 & 0.000 \\
$\left(\mathrm{LP}_{4}-\mathrm{RD}\right)=0$ vs. $\left(\mathrm{LP}_{4}-\mathrm{RD}\right) \neq 0$ & 1.75 & 0.118 \\
\hline
\end{tabular}

the amount of paper money outstanding per capita.

One possible explanation for the negative trend, controlling for the per capita amount of bills in circulation, lies in the nature of these bills as zero-coupon bonds. The majority of the value of the bills was in their security to deliver their face value in real money on the date of redemption. The 1767 bills as zero-coupon bonds appeared to be secure, in that they were backed by a sinking fund administered by the colony’s government held in London. In 1773, 1774, and particularly 1775 , colonial sentiment regarding an imminent break with the mother country was rising. If Maryland colonists felt that the redemption of the 1767 bills via a sinking fund would not happen as promised if Maryland broke with Britain, then the current value of these bills would fall. The sinking fund, after all, would be in the hands of the enemy (Behrens 1923, pp. 56-8, 88-94; Price 1977, pp. 8, 24). This effect added some RD to the 1767 bills and so gives the appearance that the overall LP of Maryland’s paper money was shrinking.

The most interesting variable in Table 8 is the positive and statistically significant effect of amounts of paper money per capita in circulation on (LP - RD). Placing more paper money in circulation increased the strain on executing redemptions as promised. As such, RD should not fall when the amounts of paper money in circulation are increased. Therefore, increases in LP, controlling for the secular trend, must account for the positive association between the amounts of paper money in circulation per capita and (LP - RD). 
Table 8. Determinants of $r^{*}$ and (LP - RD) at 6 and 8 Percent Discount Rates

$$
\left(\mathrm{LP}_{8}-\mathrm{RD}\right)=\begin{array}{lll}
76.3^{* * *} & +0.0824 \mathrm{MT} / \mathrm{Pop}^{* *} & -0.0430 \mathrm{Year}^{* * *} \\
(15.1) & (0.0238) & (0.0085)
\end{array}
$$

$\mathrm{N}=9$, Adjusted $\mathrm{R}^{2}=.80, \mathrm{~F}=17.34 * * *$, Durbin-Watson Statistic $=1.8722^{* *}$

$$
\begin{aligned}
& \left(\mathrm{LP}_{6}-\mathrm{RD}\right)=69.5^{* * *}+0.0774 \mathrm{MT} / \mathrm{Pop}^{* *} \quad-0.0393 \text { Year*** }^{* *} \\
& \text { (14.9) (0.0236) (0.0085) }
\end{aligned}
$$

$\mathrm{N}=9$, Adjusted $\mathrm{R}^{2}=.77, \mathrm{~F}=14.01 * * *$, Durbin-Watson Statistic $=1.9382 * *$

$r^{*}=\begin{array}{lll}-816.5^{* * *} & -0.9393 \mathrm{MT} / \mathrm{Pop}^{* *} & +0.4641 \mathrm{Year}^{* * *} \\ (221.0) & (0.3491) & (0.1252)\end{array}$

$\mathrm{N}=9$, Adjusted $\mathrm{R}^{2}=65.5, \mathrm{~F}=8.58^{* *}$, Durbin-Watson Statistic $=1.8271^{* *}$

Sources: Tables 5 and 6. The Maryland population (Pop) is taken from Carter (2006, v. 5, p. 652), with linear interpolation used to find data for years between decades.

Notes: MT = Maryland bills of credit currently outstanding measured at face value. From equation (2), [MEV $\left.\mathrm{APV}_{6}\right]=\left[\mathrm{LP}_{6}-\mathrm{RD}\right]$ and $\left[\mathrm{MEV}-\mathrm{APV}_{8}\right]=\left[\mathrm{LP}_{8}-\mathrm{RD}\right]$. See the text for the construction of $r^{*}$. Standard error terms are in parentheses. The null of hypothesis of no serial correlation cannot be rejected at the 5 percent level. Minitab Version 15 was used to run all regressions and generate all test statistics.

*** indicates statistical significance above the 0.01 level.

** indicates statistical significance above the 0.05 level.

The more paper money in circulation per capita, the more that paper money gained the quality of "moneyness” for which people were willing to pay. More paper money in circulation per capita increased its familiarity and ubiquitous usage, which in turn led the public to increasingly treat this money less as a pure barter asset and more like a fiat currency. This process was accomplished by the public increasingly not time-discounting these bills when used in trade as much as would be required if they were just non-money bonds, other things equal.

Table 8 also reports the determinants of $r^{*}$, where $r^{*}$ is regressed against the same independent variables as was (LP - RD). By construction, $\Delta(\mathrm{LP}-\mathrm{RD})=-\mathrm{a} \Delta r^{*}$, where $\mathrm{a}>0$. Therefore, the results should be comparable when replacing (LP - RD) with $r^{*}$, except that the signs on the coefficients of the independent variables should be reversed. Table 8 confirms this outcome. The results for $r^{*}$ and (LP - RD) corroborate each other. The $r^{*}$ regression also aids in interpreting the process of adjustment. As more bills per capita were put into circulation, 
controlling for the secular trend, subjects reduced the rate $\left(r^{*}\right)$ at which they time-discounted these bills, because these bills were serving more and more as a preferable medium of exchange compared with their next best barter alternative. Adding this medium-of-exchange use value to the bills' non-money real-asset bond value meant that subjects did not have to discount the bills as much to determine their present value compared with how much they would have to discount the bills if they were just non-money real-asset bonds.

From the beginning, Maryland's goal was not solely to pay off its war debts, but to create a currency-like instrument that could serve as a substitute in internal trade for its prior legaltender paper money and for real (specie) money. The positive association between paper money per capita and the liquidity premium (negative association between paper money per capita and $\left.r^{*}\right)$ implies that further emissions would have helped the colony avoid "the Want of paper Currency” of which Governor Sharpe warned (Archives of Maryland, v. 14, p. 174).

One particular effort of the Maryland legislature which may have enhanced the liquidity premium was the clause in the 1774 Act which ensured equitable geographic distribution of the bills by setting county loan quotas. An equitable distribution of bills was important, because it made the bills more ubiquitous throughout the colony and so enhanced their breadth and depth of usage as a medium of exchange within the colony. If one county lacked bills (if the paper money per capita was low in that area), then those few who did manage to acquire bills might find the bill's unfamiliarity among their neighbors reduced the bill's “moneyness” value as a medium of exchange. Striking a balance between counties, on the basis of population, was the best way to ensure that the bills would be a familiar means of payment throughout the colony and so push the bills toward being treated more and more like a fiat currency rather than as just a real barter asset. The nature of the distribution clause in the 1774 emission, along with the sentiment that 
the bills "may be distributed as equally and diffused as generally throughout the Province as may be” (Archives of Maryland, v. 64, p. 245), implies that the Maryland legislature sought to make their third non-legal-tender paper money emission more effective through the use of a geographically segmented monetary distribution to enhance the money’s familiarity and universality of usage in the colony.

The positive association between paper money per capita and the liquidity premium (negative association between paper money per capita and $r^{*}$ ) is also consistent with the colonies being under-monetized economies (Greene and Jellison 1961, p. 508; Rousseau 2006).

Maryland's effort to create a non-legal-tender paper currency with some fiat currency attributes out of tradable debt instruments was having some success in overcoming its under-monetized condition. Maryland's paper money was beginning the transition from a commodity or asset money to a fiat currency. While the Revolution cut Maryland's post-1764 non-legal-tender monetary experiment short, the evidence indicates that Maryland made progress in adapting the design of their paper money acts over these nine years, thus enhancing their success.

\section{Conclusions}

Creating Maryland's paper money emissions during the years 1767-1775 was an arduous and daunting legislative process. While maneuvering through political battles, sidestepping legal constraints, and alleviating fears of a monetary collapse, the Maryland legislature's Upper and Lower Houses came together to create three laws which emitted zero-coupon bonds known as bills of credit as non-legal-tender debt instruments. These bills were designed to take the place of the legal-tender bills Britain had sought to prevent the colonies from creating. Through the use of updated estimates of the actual amounts of paper money emitted, liquidity premium theory, and statistical analysis, it was shown that these bills did, on some level, function as a paper "money." 
The bills fulfilled their duty largely due to a series of intricate improvements to the legal framework, such as geographically segmented distribution and the use of a contingency expense reserve, made by the Maryland legislature over successive emission acts.

From 1767 through 1775 Maryland emitted substantially less paper money than previously thought. The corrections provided here to the overestimates in the prior literature are an important contribution in their own right. Overall, Maryland's paper money in these years was primarily a real asset or commodity money and not a fiat currency. Just over 80 percent of its market value was accounted for by its expected real asset present value. Just under 20 percent was accounted for by its liquidity premium. As such, Maryland's bills possessed value to some degree because they served as a money or preferred medium of exchange for local transactions in excess of the next best barter alternative. Maryland's paper money was beginning a transition from being a commodity or real asset money toward being treated like a fiat currency. The Revolution and the consequent paper-money chaos caused by this war and its aftermath cut this transition short and brought this line of monetary experimentation to an end (Behrens 1923, pp. 56-77, 88-94; Grubb 2003, 2006; Price 1977, pp. 24-5).

The liquidity premium attached to Maryland's bills of credit between 1767 and 1775 was positively associated with the quantity of bills per capita emitted. This association was due to how Maryland learned over time to enhance the familiarity and general usage of the bills to help mitigate the effects of being in an under-monetized economy. The liquidity premium was created through the public not discounting the bills as much as they should have if the bills were just regarded as non-money real-asset bonds.

Lastly, Maryland's non-legal-tender paper money in this period never depreciated. It traded below face value not due to depreciation, but because it was primarily a bond with a 
payoff in the future and so had to be time-discounted to assess its present value. Scholars have simply confused time-discounting for depreciation. In fact, the presence of a positive liquidity premium indicates that Maryland's paper money in this period circulated at an appreciated value, i.e. at a value in excess of its real asset present value. 


\section{Reference}

Archives of Maryland, 1883-1972, Vol. 1-72. Baltimore, MD: Maryland Historical Society.

Barlow, J. Jackson, ed., 2012. To Secure the Blessings of Liberty: Selected Writings of Gouverneur Morris. Indianapolis, IN: Liberty Fund.

Behrens, Kathryn L., 1923. “Paper Money in Maryland, 1727-1789.” Johns Hopkins University Studies in Historical and Political Science, 41, no. 1, pp. 9-98.

Brock, Leslie V., 1975. The Currency of the American Colonies, 1700-1764. New York: Arno Press.

, 1992. “The Colonial Currency, Prices, and Exchange Rates.” Essays in History, 34, pp. 70-132 [posthumously published].

Carter, Susan B., et al., 2006. Historical Statistics of the United States: Earliest Times to the Present Millennial Edition, Vol. 5. New York: Cambridge University Press.

Davis, Andrew McFarland. 1964. Colonial Currency Reprints, 1682-1751, vols. 1-4. New York: Augustus M. Kelley.

Elliot, Jonathan. 1843. "Funding System of the United States and Great Britain,” House of Representatives Document No. 15 (Vol. II. Executive Documents), $28^{\text {th }}$ Congress, $1^{\text {st }}$ Session, Read on Dec. 16, 1843. [Reprinted 1971. New York: Burt Franklin].

Ernst, Joseph E., 1973. Money and Politics in America, 1755-1775. Chapel Hill, NC: University of North Carolina Press.

Ferguson, E. James, et al., eds., 1988. The Papers of Robert Morris, 1781-1784, Vol. 7. Pittsburgh, PA: University of Pittsburgh Press.

Greene, Jack P., 1980. “The Seven Years’ War and the American Revolution: The Causal Relationship Reconsidered.” In Marshall, Peter, and Williams, Glyn, eds., The British Atlantic Empire before the American Revolution. London: Frank Cass, Pp. 85-105. , and Jellison, Richard M., 1961. "The Currency Act of 1764 in Imperial-Colonia Relations, 1764-1776.” The William and Mary Quarterly, 18, no. 4, pp. 485-518.

Grubb, Farley, 2003. “Creating the U.S.-Dollar Currency Union, 1748-1811: A Quest for Monetary Stability or a Usurpation of State Sovereignty for Personal Gain?” American Economic Review, 93, no. 5, pp. 1778-1798.

, 2006. "The U.S. Constitution and Monetary Powers: An Analysis of the 1787 Constitutional Convention and the Constitutional Transformation of the U.S. Monetary System,” Financial History Review, 13, no. 1, pp. 43-71. 
2012a. “Is Paper Money Just Paper Money? Experimentation and Local Variation in the Fiat Paper Monies Issued by the Colonial Governments of British North America, 16901775: Part I.” [NBER Working Paper \#17997, Apr. 2012]

http://www.nber.org/papers/w17997

2012b. "Chronic Specie Scarcity and Efficient Barter: The Problem of Maintaining an Outside Money Supply in British Colonial America,” NBER Working Paper \#18099, May 2012, http://www.nber.org/papers/w18099

, 2013. “Colonial New Jersey’s Paper Money Regime, 1709-1775: A Forensic Accounting Reconstruction of the Data,” NBER Working Paper \#19710, December 2013, http://www.nber.org/papers/w19710

, 2014. “A New Approach to Solving the Colonial Monetary Puzzle: Evidence from New Jersey, 1709-1775.” [NBER Working Paper \#19903, February 2014] http://www.nber.org/papers/w19903

Homer, Sidney, and Sylla, Richard, 1991. A History of Interest Rates. New Brunswick, NJ: Rutgers University Press, third edition.

Hutchinson, William T., and Rachal, William M. E., eds., 1962. The Papers of James Madison, Vol. 1. Chicago: University of Chicago Press.

Journals of the Continental Congress, 1774-1789, Vols. 1-34. 1904-1937. Washington D.C.: Government Printing Office.

Labaree, Leonard W. ed., 1966-1970. The Papers of Benjamin Franklin, Vols. 9-14. New Haven, CT: Yale University Press.

McCusker, John J., 1978. Money and Exchange in Europe and America, 1600-1775. Chapel Hill, NC: University of North Carolina Press.

Nettels, Curtis Putnam. 1934. The Money Supply of the American Colonies before 1720. Madison, WI: University of Wisconsin Press.

Newman, Eric P., 2008. The Early Paper Money of America. Iola, WI: Krause Publications, $5^{\text {th }}$ edition.

Price, Jacob M., 1977. “The Maryland Bank Stock Case: British-American Financial and Political Relations Before and After the American Revolution.” In Land, Aubrey C., Carr, Lois Green, and Papenfuse, Edward C., eds., Law, Society, and Politics in Early Maryland. Baltimore: Johns Hopkins Univ. Press, Pp. 3-40.

Puls, Mark. 2008. Henry Knox, Visionary General of the American Revolution. New York: Palgrave Macmillan. 
Redish, Angela. 1993. "Anchors Aweigh: The Transition from Commodity Money to Fiat Money in Western Economies.” Canadian Journal of Economics 26, no. 4, pp. 777-795.

Rousseau, Peter L., 2006. "A Common Currency: Early US Monetary Policy and the Transition to the Dollar.” Financial History Review 13, no. 1, pp. 97-122.

Scott, Kenneth. 1957. Counterfeiting in Colonial America. Philadelphia: University of Pennsylvania Press.

Smith, Bruce, 1985. "Some Colonial Evidence on Two Theories of Money: Maryland and the Carolinas.” Journal of Political Economy, 93, no. 6, pp. 1178-1211.

Smith, Paul H., 1976-1994. Letters of Delegates to Congress, 1774-1789, Vols. 1-21. Washington, DC: Library of Congress. 